\title{
One-Pot Synthesis of Aryl Boronic Acids and Aryl Trifluoroborates by Ir-Catalyzed Borylation of Arenes
}

\section{Supporting Information}

Jaclyn M. Murphy, C. Christoph Tzschucke, and John F. Hartwig*

Yale University, P.O. Box 208107, New Haven, Connecticut 06520 and

University of Illinois, 600 South Matthews Avenue, Urbana, Illinois, 61801 
General Experimental Information and Reagent Information: Borylations of arenes were conducted in sealed vessels. $[\operatorname{Ir}(\mathrm{COD}) \mathrm{Cl}]_{2}$ and $[\operatorname{Ir}(\mathrm{COD})(\mathrm{OMe})]_{2}$ were prepared according to literature procedure. ${ }^{1}$ Conversion of aryl boronic esters to either arylboronic acids or aryltrifluoroborates were conducted under ambient atmosphere. All arenes, $\mathrm{B}_{2} \mathrm{pin}_{2}, \mathrm{NaIO}_{4}$, and $\mathrm{KHF}_{2}$ were bought from commercial sources and were used without further purification. Borylations were performed using THF that was degassed by purging with nitrogen for $45 \mathrm{~min}$ and then dried with a solvent purification system using a $1 \mathrm{~m}$ column containing activated alumina. For the conversion of arylboronic esters to arylboronic acids and potassium aryltrifluoroborates, ACS grade THF was purchased from Aldrich and was used without further purification.

GC-MS data were obtained on an Agilient 6890-N GC system containing an Alltech EC-1 capillary column and an Agilient 5973 mass selective detector. ${ }^{1} \mathrm{H}-\mathrm{NMR}$, ${ }^{13} \mathrm{C}-\mathrm{NMR},{ }^{11} \mathrm{~B}-\mathrm{NMR}$, and ${ }^{19} \mathrm{~F}-\mathrm{NMR}$ spectra were obtained on a $400 \mathrm{MHz}$ or $500 \mathrm{MHz}$ Varian Unities.

Conversion of 1-methoxy-3-trifluoromethylbenzene to potassium (3methoxy-5-trifluoromethylphenyl)trifluoroborate. In a glove box, 1-methoxy-3trifluoromethylbenzene $(0.72 \mathrm{~mL}, 5.0 \mathrm{mmol}), \mathrm{B}_{2} \mathrm{pin}_{2},(0.893 \mathrm{~g}, 3.52 \mathrm{mmol})$, $[\operatorname{Ir}(\mathrm{COD})(\mathrm{OMe})]_{2}(3.3 \mathrm{mg}, 5.0 \mu \mathrm{mol})$, dtbpy $(2.5 \mathrm{mg}, 10.0 \mu \mathrm{mol})$, and THF $(5.0 \mathrm{~mL})$ were combined. The reaction mixture was heated in a sealed vessel at $80{ }^{\circ} \mathrm{C}$ for $16 \mathrm{~h}$. The reaction was allowed to cool to room temperature, and then $\mathrm{H}_{2} \mathrm{O}(3.0 \mathrm{~mL})$ and $\mathrm{KHF}_{2}$ $(2.30 \mathrm{~g}, 28.5 \mathrm{mmol})$ were added. The reaction mixture was stirred for $5 \mathrm{~h}$ at room temperature. The solvent mixture was removed under vacuum, and the resulting mixture was extracted into acetone. The acetone solution was then reduced under vacuum to yield a mixture of potassium aryltrifluoroborate and pinacol. The crude product was rinsed with hexanes and heated at $60{ }^{\circ} \mathrm{C}$ under vacuum $(6 \mathrm{mtorr})$ to remove pinacol. Purified product was recovered in $85 \%$ yield as a white solid. ${ }^{1} \mathrm{H}$ NMR (500 MHz, acetone- $\left.d_{6}\right) \delta 7.36(\mathrm{~s}, 1 \mathrm{H}), \delta 7.25(\mathrm{~s}, 1 \mathrm{H}), \delta 6.83(\mathrm{~s}, 1 \mathrm{H}), \delta 3.77(\mathrm{~s}, 3 \mathrm{H}) .{ }^{11} \mathrm{~B}$ NMR $(600$ $\mathrm{MHz}$, acetone- $\left.d_{6}\right): \delta 3.73(q, \mathrm{~J}=155 \mathrm{~Hz}) .{ }^{19} \mathrm{~F}$ NMR $\left(600 \mathrm{MHz}\right.$, acetone- $\left.d_{6}\right): \delta-63.4(s), \delta-$ $144.8(q, \mathrm{~J}=44 \mathrm{~Hz}) .{ }^{13} \mathrm{C}$ NMR $\left(500 \mathrm{MHz}\right.$, acetone- $\left.d_{6}\right): \delta 160.5, \delta 109.8, \delta 98.5, \delta 54.9$.

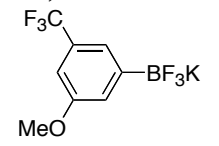

Conversion of 1,3-(trifluoromethyl)benzene to potassium (3-methoxy-5trifluoromethylphenyl)trifluoroborate. In a glove box, 1,3-(trifluoromethyl)benzene (0.78 mL, $5.0 \mathrm{mmol}), \mathrm{B}_{2} \mathrm{pin}_{2},(0.886 \mathrm{~g}, 3.94 \mathrm{mmol})$, [Ir(COD)(OMe) $]_{2}(3.3 \mathrm{mg}, 5.0$ $\mu \mathrm{mol})$, dtbpy $(2.9 \mathrm{mg}, 10.1 \mu \mathrm{mol})$, and THF $(5.0 \mathrm{~mL})$ were combined. The reaction mixture was heated in a sealed vessel at $80{ }^{\circ} \mathrm{C}$ for $16 \mathrm{~h}$. The reaction was allowed to cool to room temperature, and then $\mathrm{H}_{2} \mathrm{O}(3.0 \mathrm{~mL})$ and $\mathrm{KHF}_{2}(2.22 \mathrm{~g}, 28.5 \mathrm{mmol})$ were added. The reaction mixture was stirred for $5 \mathrm{~h}$ at room temperature. The solvent mixture was removed under vacuum, and the resulting mixture was extracted into acetone. The acetone solution was then reduced under vacuum to yield a mixture of potassium aryltrifluoroborate and pinacol. The crude product was rinsed with hexanes and heated at $60{ }^{\circ} \mathrm{C}$ under vacuum (6 mtorr) to remove pinacol. Purified product was recovered in $82 \%$ yield as a white solid. ${ }^{1} \mathrm{H}$ NMR $\left(500 \mathrm{MHz}\right.$, acetone- $\left.d_{6}\right) \delta 8.01(\mathrm{~s}, 2 \mathrm{H}), \delta 7.67$ (s, 1 
H). ${ }^{11} \mathrm{~B}$ NMR $\left(600 \mathrm{MHz}\right.$, acetone- $\left.d_{6}\right): \delta 3.43(q, \mathrm{~J}=155 \mathrm{~Hz}) .{ }^{19} \mathrm{~F}$ NMR $(500 \mathrm{MHz}$, acetone$\left.d_{6}\right): \delta-63.4(s), \delta-144.8(q, \mathrm{~J}=44 \mathrm{~Hz}) .{ }^{13} \mathrm{C}$ NMR $\left(500 \mathrm{MHz}\right.$, acetone- $\left.d_{6}\right): \delta 132.5, \delta 126.6$, $\delta 124.4, \delta 119.4$

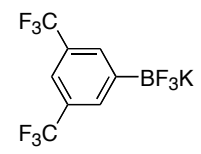

\section{Conversion of 1,3 -dichlorobenzene to potassium $(3,5-$}

dichlorophenyl)trifluoroborate. In a glove box, 1,3-dichlorobenzene $(0.57 \mathrm{~mL}, 5.0$ $\mathrm{mmol}), \mathrm{B}_{2} \mathrm{pin}_{2},(0.915 \mathrm{~g}, 3.60 \mathrm{mmol}),[\operatorname{Ir}(\mathrm{COD})(\mathrm{OMe})]_{2}(3.6 \mathrm{mg}, 5.8 \mu \mathrm{mol})$, dtbpy $(3.3$ $\mathrm{mg}, 12 \mu \mathrm{mol})$, and THF $(10.0 \mathrm{~mL})$ were combined. The reaction mixture was heated in a sealed vessel at $80{ }^{\circ} \mathrm{C}$ for $16 \mathrm{~h}$. The reaction was allowed to cool to room temperature, and then $\mathrm{H}_{2} \mathrm{O}(3.0 \mathrm{~mL})$ and $\mathrm{KHF}_{2}(2.23 \mathrm{~g}, 28.5 \mathrm{mmol})$ were added. The reaction mixture was stirred for $5 \mathrm{~h}$ at room temperature. The solvent mixture was removed under vacuum, and the resulting mixture was extracted into acetone. The acetone solution was then reduced under vacuum to yield a mixture of potassium aryltrifluoroborate and pinacol. The crude product was rinsed with hexanes and heated at $60{ }^{\circ} \mathrm{C}$ under vacuum (6 mtorr) to remove pinacol. Purified product was recovered in $66 \%$ yield as a white solid. ${ }^{1} \mathrm{H}$ NMR $\left(500 \mathrm{MHz}\right.$, acetone- $\left.d_{6}\right) \delta 7.34(\mathrm{~s}, 1 \mathrm{H}), \delta 7.05(\mathrm{~s}, 2 \mathrm{H}) .{ }^{11} \mathrm{~B}$ NMR $(500$ $\mathrm{MHz}$, acetone- $\left.d_{6}\right): \delta 3.47 .{ }^{13} \mathrm{C}$ NMR $\left(600 \mathrm{MHz}\right.$, acetone- $\left.d_{6}\right): \delta 133.8, \delta 130.7, \delta 125.3 .{ }^{19} \mathrm{~F}$ NMR (600 MHz, acetone- $\left.d_{6}\right): \delta-143.3$.

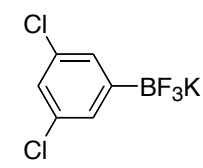

Conversion of 1-methoxycarbonyl-3-methylbenzene to potassium (3methoxycarbonyl-5-methylphenyl)trifluoroborates. In a glove box, 1methoxycarbonyl-3-methylbenzene $(0.71 \mathrm{~mL}, 5.0 \mathrm{mmol}), \mathrm{B}_{2} \operatorname{pin}_{2},(0.887 \mathrm{~g}, 3.50 \mathrm{mmol})$, $[\mathrm{Ir}(\mathrm{COD})(\mathrm{OMe})]_{2}(3.2 \mathrm{mg}, 4.8 \mu \mathrm{mol})$, dtbpy $(2.7 \mathrm{mg}, 10 \mu \mathrm{mol})$, and THF $(10.0 \mathrm{~mL})$ were combined. The reaction mixture was heated in a sealed vessel at $80{ }^{\circ} \mathrm{C}$ for $16 \mathrm{~h}$. The reaction was allowed to cool to room temperature, and then $\mathrm{H}_{2} \mathrm{O}(3.0 \mathrm{~mL})$ and $\mathrm{KHF}_{2}$ $(2.26 \mathrm{~g}, 28.5 \mathrm{mmol})$ were added. The reaction mixture was stirred for $5 \mathrm{~h}$ at room temperature. The solvent mixture was removed under vacuum, and the resulting mixture was extracted into acetone. The acetone solution was then reduced under vacuum to yield a mixture of aryltrifluoroborate and pinacol. The crude product was rinsed with hexanes and heated at $60{ }^{\circ} \mathrm{C}$ under vacuum (6 mtorr) to remove pinacol. Clean product was recovered in $75 \%$ yield as a white solid. ${ }^{1} \mathrm{H}$ NMR $\left(500 \mathrm{MHz}\right.$, acetone- $\left.d_{6}\right) \delta 7.99(\mathrm{~s}, 1$ $\mathrm{H}), \delta 7.50(\mathrm{~s}, 2 \mathrm{H}), \delta 3.77(\mathrm{~s}, 3 \mathrm{H}), \delta 2.26(\mathrm{~s}, 3 \mathrm{H}) .{ }^{11} \mathrm{~B}$ NMR $\left(500 \mathrm{MHz}\right.$, acetone- $\left.d_{6}\right)$ :

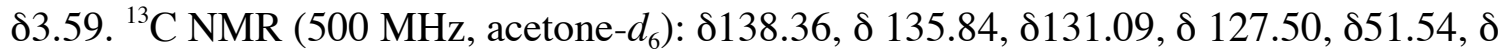
21.38. ${ }^{19} \mathrm{~F}$ NMR (500 MHz, acetone- $\left.d_{6}\right): \delta-142.4$.

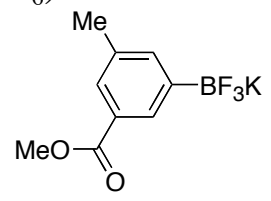

Conversion of 1,3-dibromobenzene to potassium (3,5dibromophenyl)trifluoroborate. In a glove box, 1,3-dibromobenzene $(0.60 \mathrm{~mL}, 5.0$ 
$\mathrm{mmol}), \mathrm{B}_{2} \mathrm{pin}_{2},(0.900 \mathrm{~g}, 3.54 \mathrm{mmol}),[\operatorname{Ir}(\mathrm{COD})(\mathrm{OMe})]_{2}(3.2 \mathrm{mg}, 4.8 \mu \mathrm{mol}), \mathrm{dtbpy}(3.5$ $\mathrm{mg}, 13 \mu \mathrm{mol})$, and THF $(10.0 \mathrm{~mL})$ were combined. The reaction mixture was heated in a sealed vessel at $80{ }^{\circ} \mathrm{C}$ for $16 \mathrm{~h}$. The reaction was allowed to cool to room temperature, and then $\mathrm{H}_{2} \mathrm{O}(3.0 \mathrm{~mL})$ and $\mathrm{KHF}_{2}(2.21 \mathrm{~g}, 28.3 \mathrm{mmol})$ were added. The reaction mixture was stirred for $5 \mathrm{~h}$ at room temperature. The solvent mixture was removed under vacuum, and the resulting mixture was extracted into acetone. The acetone solution was then reduced under vacuum to yield a mixture of aryltrifluoroborate and pinacol. The crude product was rinsed with hexanes and heated at $60{ }^{\circ} \mathrm{C}$ under vacuum (6 mtorr) to remove pinacol. Purified product was recovered in $72 \%$ yield as a white solid. ${ }^{1} \mathrm{H}$ NMR $\left(500 \mathrm{MHz}\right.$, acetone- $\left.d_{6}\right) \delta 7.52(\mathrm{~s}, 2 \mathrm{H}), \delta 7.36(\mathrm{~s}, 1 \mathrm{H}) .{ }^{11} \mathrm{~B}$ NMR $\left(500 \mathrm{MHz}\right.$, acetone- $\left.d_{6}\right)$ : $\delta 3.11(q, \mathrm{~J}=165 \mathrm{~Hz}) .{ }^{13} \mathrm{C}$ NMR $\left(600 \mathrm{MHz}\right.$, acetone- $\left.d_{6}\right)$ : $\delta 134.1, \delta 130.7, \delta 122.4 .{ }^{19} \mathrm{~F}$ NMR (500 MHz, acetone- $\left.d_{6}\right): \delta 143.4(q, \mathrm{~J}=59 \mathrm{~Hz})$.

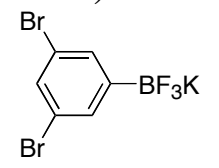

\section{Conversion of 1,3-dimethoxybenzene to potassium $(3,5-$}

dimethoxyphenyl)trifluoroborate In a glove box, 1,3-dimethoxybenzene $(0.66 \mathrm{~mL}, 5.0$ $\mathrm{mmol}), \mathrm{B}_{2} \mathrm{pin}_{2},(0.892 \mathrm{~g}, 3.51 \mathrm{mmol}),[\mathrm{Ir}(\mathrm{COD})(\mathrm{OMe})]_{2}(3.6 \mathrm{mg}, 5.5 \mu \mathrm{mol})$, dtbpy $(3.5$ $\mathrm{mg}, 13 \mu \mathrm{mol})$, and THF $(10.0 \mathrm{~mL})$ were combined. The reaction mixture was heated in a sealed vessel at $80{ }^{\circ} \mathrm{C}$ for $16 \mathrm{~h}$. The reaction was allowed to cool to room temperature, and then $\mathrm{H}_{2} \mathrm{O}(3.0 \mathrm{~mL})$ and $\mathrm{KHF}_{2}(2.28 \mathrm{~g}, 29.1 \mathrm{mmol})$ were added. The reaction mixture was stirred for $5 \mathrm{~h}$ at room temperature. The solvent mixture was removed under vacuum, and the resulting mixture was extracted into acetone. The acetone solution was then reduced under vacuum to yield a mixture of aryltrifluoroborate and pinacol. The crude product was rinsed with hexanes and heated at $60{ }^{\circ} \mathrm{C}$ under vacuum (6 mtorr) to remove pinacol, and clean product was recovered in $93 \%$ yield as a white solid. ${ }^{1} \mathrm{H}$ NMR $\left(500 \mathrm{MHz}\right.$, acetone- $\left.d_{6}\right) \delta 6.64(\mathrm{~s}, 2 \mathrm{H}), \delta 6.12(\mathrm{~s}, 1 \mathrm{H}), \delta 3.66(\mathrm{~s}, 6 \mathrm{H}) .{ }^{11} \mathrm{~B} \mathrm{NMR}(500$ $\mathrm{MHz}$, acetone- $\left.d_{6}\right): \delta 4.10(q, \mathrm{~J}=\mathrm{XX} \mathrm{Hz}) .{ }^{13} \mathrm{C}$ NMR $\left(500 \mathrm{MHz}\right.$, acetone- $\left.d_{6}\right): \delta 160.56, \delta$ $109.76, \delta 98.54, \delta 54.95 .{ }^{19} \mathrm{~F}$ NMR $\left(500 \mathrm{MHz}\right.$, acetone- $\left.d_{6}\right): \delta 142.1$.

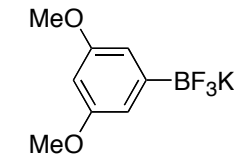

Conversion of 1-chloro-3-trifluoromethylbenzene to potassium (3-chloro-5trifluoromethylphenyl)trifluoroborate. In a glove box, 1-chloro-3trifluoromethylbenzene $(0.72 \mathrm{~mL}, 5.0 \mathrm{mmol}), \mathrm{B}_{2} \mathrm{pin}_{2},(0.893 \mathrm{~g}, 3.52 \mathrm{mmol})$, $[\operatorname{Ir}(\mathrm{COD})(\mathrm{OMe})]_{2}(3.3 \mathrm{mg}, 5.0 \mu \mathrm{mol})$, dtbpy $(2.5 \mathrm{mg}, 9.3 \mu \mathrm{mol})$, and THF $(10.0 \mathrm{~mL})$ were combined. The reaction mixture was heated in a sealed vessel at $80{ }^{\circ} \mathrm{C}$ for $16 \mathrm{~h}$. The reaction was allowed to cool to room temperature, and then $\mathrm{H}_{2} \mathrm{O}(3.0 \mathrm{~mL})$ and $\mathrm{KHF}_{2}$ $(2.30 \mathrm{~g}, 29.4 \mathrm{mmol})$ were added. The reaction mixture was stirred for $5 \mathrm{~h}$ at room temperature. The solvent mixture was removed under vacuum, and the resulting mixture was extracted into acetone. The acetone solution was then reduced under vacuum to yield a mixture of aryltrifluoroborate and pinacol. The crude product was rinsed with hexanes and heated at $60{ }^{\circ} \mathrm{C}$ under vacuum ( 6 mtorr) to remove pinacol. Clean product 
was recovered in $91 \%$ yield as a white solid. ${ }^{1} \mathrm{H}$ NMR $\left(500 \mathrm{MHz}\right.$, acetone- $\left.d_{6}\right): \delta 7.02(\mathrm{~s}, 1$ $\mathrm{H}), \delta 6.95(\mathrm{~s}, 1 \mathrm{H}), \delta 6.60(\mathrm{~s}, 1 \mathrm{H}), \delta 3.72(\mathrm{~s}, 3 \mathrm{H}) .{ }^{11} \mathrm{~B}$ NMR $\left(300 \mathrm{MHz}\right.$, acetone- $\left.d_{6}\right): \delta 8.36$ $(q, \mathrm{~J}=78 \mathrm{~Hz}) .{ }^{13} \mathrm{C}$ NMR $\left(500 \mathrm{MHz}\right.$, acetone- $\left.d_{6}\right): \delta 160.43, \delta 133.29, \delta 124.65, \delta 116.05, \delta$ $111.64, \delta 55.29 .{ }^{19} \mathrm{~F}$ NMR (500 MHz, acetone- $\left.d_{6}\right): \delta 142.7$.

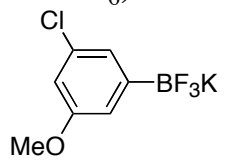

\section{Conversion of 1-chloro-3-methylbenzene to potassium (3-chloro-5-}

trifluoromethylphenyl)trifluoroborate. In a glove box, 1-chloro-3-methylbenzene (0.59 mL, $5.0 \mathrm{mmol}), \mathrm{B}_{2} \operatorname{pin}_{2},(0.895 \mathrm{~g}, 3.52 \mathrm{mmol}),[\operatorname{Ir}(\mathrm{COD})(\mathrm{OMe})]_{2}(3.1 \mathrm{mg}, 5.0$ $\mu \mathrm{mol})$, dtbpy $(3.0 \mathrm{mg}, 11.2 \mu \mathrm{mol})$, and THF $(10.0 \mathrm{~mL})$ were combined. The reaction mixture was heated in a sealed vessel at $80{ }^{\circ} \mathrm{C}$ for $16 \mathrm{~h}$. The reaction was allowed to cool to room temperature, and then $\mathrm{H}_{2} \mathrm{O}(3.0 \mathrm{~mL})$ and $\mathrm{KHF}_{2}(2.28 \mathrm{~g}, 29.2 \mathrm{mmol})$ were added. The reaction mixture was stirred for $5 \mathrm{~h}$ at room temperature. The solvent mixture was removed under vacuum, and the resulting mixture was extracted into acetone. The acetone solution was then reduced under vacuum to yield a mixture of aryl boronic acid and pinacol. The crude product was rinsed with hexanes and heated at $60{ }^{\circ} \mathrm{C}$ under vacuum (6 mtorr) to remove pinacol. Clean product was recovered in $97 \%$ yield as a white solid. ${ }^{1} \mathrm{H}$ NMR (400 MHz, acetone- $\left.d_{6}\right)$ : $\delta 7.32$ (s, $\left.1 \mathrm{H}\right), \delta 7.19$ (s, $\left.1 \mathrm{H}\right), \delta 6.86$ (s, 1 $\mathrm{H}), \delta 2.22(\mathrm{~s}, 3 \mathrm{H}) .{ }^{11} \mathrm{~B}$ NMR $\left(300 \mathrm{MHz}\right.$, acetone- $\left.d_{6}\right): \delta 8.35(q, \mathrm{~J}=155 \mathrm{~Hz}) .{ }^{13} \mathrm{C} \mathrm{NMR}$ $\left(500 \mathrm{MHz}\right.$, acetone- $\left.d_{6}\right): \delta 138.2, \delta 132.0, \delta 131.6, \delta 129.3, \delta 126.2, \delta 21.2 .{ }^{19} \mathrm{~F} \mathrm{NMR}$ $\left(600 \mathrm{MHz}\right.$, acetone- $\left.d_{6}\right): \delta 142.8(q, \mathrm{~J}=62 \mathrm{~Hz})$.

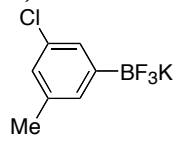

\section{Conversion of $m$-xylylboronic ester to potassium $(3,5-$}

dimethylphenyl)trifluoroborate. In a glove box, $m$-xylene $(0.29 \mathrm{~mL}, 2.0 \mathrm{mmol})$, $\mathrm{B}_{2} \operatorname{pin}_{2},(0.364 \mathrm{~g}, 1.43 \mathrm{mmol}), \mathrm{HBpin}(30 \mu \mathrm{L}, 0.02 \mathrm{mmol}),[\mathrm{Ir}(\mathrm{COD})(\mathrm{OMe})]_{2}(16.2 \mathrm{mg}$, $24.4 \mu \mathrm{mol})$, dtbpy $(1.0 \mathrm{mg}, 66.3 \mu \mathrm{mol})$, and THF $(10.0 \mathrm{~mL})$ were combined. The reaction mixture was heated in a sealed vessel at $80{ }^{\circ} \mathrm{C}$ for $16 \mathrm{~h}$. The reaction was allowed to cool to room temperature, and then $\mathrm{H}_{2} \mathrm{O}(3.0 \mathrm{~mL})$ and $\mathrm{KHF}_{2}(0.860 \mathrm{~g}, 11.0$ $\mathrm{mmol}$ ) were added. The reaction mixture was stirred for $5 \mathrm{~h}$ at room temperature. The solvent mixture was removed under vacuum, and the resulting mixture was extracted into acetone. The acetone solution was then reduced under vacuum to yield a mixture of aryltrifluoroborate and pinacol. The crude product was rinsed with hexanes and heated at $60{ }^{\circ} \mathrm{C}$ under vacuum (6 mtorr) to remove pinacol. Clean product was recovered in $61 \%$ yield as a white solid. ${ }^{1} \mathrm{H}$ NMR $\left(500 \mathrm{MHz}\right.$, acetone- $\left.d_{6}\right) \delta 7.06(\mathrm{~s}, 2 \mathrm{H}), \delta 6.62(\mathrm{~s}, 1 \mathrm{H}), \delta$ $2.16(\mathrm{~s}, 6 \mathrm{H}) .{ }^{13} \mathrm{C}$ NMR $\left(500 \mathrm{MHz}\right.$, acetone- $\left.d_{6}\right) \delta 135.2, \delta 130.5, \delta 127.3 .{ }^{11} \mathrm{~B}$ NMR $(500$ $\mathrm{MHz}$, acetone- $\left.d_{6}\right): \delta 4.36 .{ }^{19} \mathrm{~F} \mathrm{NMR}\left(500 \mathrm{MHz}\right.$, acetone- $\left.d_{6}\right): \delta 141.7(q, \mathrm{~J}=74 \mathrm{~Hz})$.

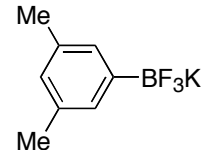


Conversion of 2-benzofuran to potassium (2-benzofuranyl)trifluoroborate. In a glove box, 2-benzofuran (0.54 mL, $2.0 \mathrm{mmol})$, HBpin, (0.07 mL, $0.500 \mathrm{mmol})$, $[\operatorname{Ir}(\mathrm{COD})(\mathrm{OMe})]_{2}(31.4 \mathrm{mg}, 0.047 \mathrm{mmol})$, dtbpy $(29.1 \mathrm{mg}, 0.108 \mathrm{mmol})$, and THF (10.0 $\mathrm{mL}$ ) were combined. The reaction mixture was heated in a sealed vessel at $80{ }^{\circ} \mathrm{C}$ for 16 h. The reaction was allowed to cool to room temperature, and then $\mathrm{H}_{2} \mathrm{O}(3.0 \mathrm{~mL})$ and $\mathrm{KHF}_{2}(2.18 \mathrm{~g}, 27.9 \mathrm{mmol})$ were added. The reaction mixture was stirred for $5 \mathrm{~h}$ at room temperature. The solvent mixture was removed under vacuum, and the resulting mixture was extracted into acetone. The acetone solution was then reduced under vacuum and the crude product mixture was heated to $60{ }^{\circ} \mathrm{C}$ under vacuum (6 mtorr) to remove pinacol. The product was recovered in $78 \%$ yield as a white solid. ${ }^{1} \mathrm{H}$ NMR $(500 \mathrm{MHz}$, acetone$\left.d_{6}\right) \delta 7.42(d, \mathrm{~J}=2 \mathrm{~Hz}, 1 \mathrm{H}), \delta 7.41(d, \mathrm{~J}=2 \mathrm{~Hz}, 1 \mathrm{H}), \delta 7.03(m, 2 \mathrm{H}), \delta 6.52(s, 1 \mathrm{H}) .{ }^{11} \mathrm{~B}$ NMR (500 MHz, acetone- $\left.d_{6}\right): \delta 2.59(q, \mathrm{~J}=156 \mathrm{~Hz}) .{ }^{13} \mathrm{C}$ NMR $\left(600 \mathrm{MHz}\right.$, acetone- $\left.d_{6}\right): \delta$ $122.3, \delta 121.8, \delta 120.6, \delta 111.2, \delta 110.6 .{ }^{19} \mathrm{~F}$ NMR (600 MHz, acetone- $\left.d_{6}\right): \delta 142.2(q, \mathrm{~J}=$ $55 \mathrm{~Hz})$.

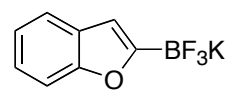

\section{Conversion of 2-benzothiophene to potassium (2-}

benzothiophenyl)trifluoroborate. In a glove box, 2-benzothiophene $(0.23 \mathrm{~mL}, 2.0$ mmol), HBpin $(3.0 \mu \mathrm{L}, 0.20 \mathrm{mmol}),[\mathrm{Ir}(\mathrm{COD})(\mathrm{OMe})]_{2}(13.4 \mathrm{mg}, 0.020 \mathrm{mmol})$, dtbpy $(11.3 \mathrm{mg}, 0.042 \mathrm{mmol})$, and THF $(10.0 \mathrm{~mL})$ were combined. The reaction mixture was heated in a sealed vessel at $80{ }^{\circ} \mathrm{C}$ for $16 \mathrm{~h}$. The reaction was allowed to cool to room temperature, and then $\mathrm{H}_{2} \mathrm{O}(3.0 \mathrm{~mL})$ and $\mathrm{KHF}_{2}(2.22 \mathrm{~g}, 28.4 \mathrm{mmol})$ were added. The reaction mixture was stirred for $5 \mathrm{~h}$ at room temperature. The solvent mixture was removed under vacuum, and the resulting mixture was extracted into acetone. The acetone solution was then reduced under vacuum to yield a mixture of aryltrifluoroborate and pinacol. The crude product was rinsed with hexanes and heated at $60{ }^{\circ} \mathrm{C}$ under vacuum (6 mtorr) to remove pinacol. Purified product was recovered in $45 \%$ yield as a light tan solid. ${ }^{1} \mathrm{H}$ NMR $\left(500 \mathrm{MHz}\right.$, acetone- $\left.d_{6}\right) \delta 7.73(d, 1 \mathrm{H}, \mathrm{J}=8 \mathrm{~Hz}), \delta 7.62(d, 1 \mathrm{H}$, $\mathrm{J}=8 \mathrm{~Hz}), \delta 7.14(m, 2 \mathrm{H}), \delta 7.08(s, 1 \mathrm{H}) .{ }^{11} \mathrm{~B}$ NMR $\left(500 \mathrm{MHz}\right.$, acetone- $\left.d_{6}\right): \delta 3.24(q$, $\mathrm{J}=146 \mathrm{~Hz}) .{ }^{13} \mathrm{C}$ NMR $\left(500 \mathrm{MHz}\right.$, acetone- $\left.d_{6}\right): \delta 124.34, \delta 123.42, \delta 122.92, \delta 122.56, \delta$ 110.62. ${ }^{19} \mathrm{~F}$ NMR $\left(600 \mathrm{MHz}\right.$, acetone- $\left.d_{6}\right): \delta 137.7(q, \mathrm{~J}=35 \mathrm{~Hz})$.<smiles>[Mg]C(Br)(Br)c1cc2ccccc2s1</smiles>

Conversion of $\boldsymbol{m}$-xylene to 3,5-dimethylphenyl boronic acid. In a glove box, $m$-xylene (1.28 mL, $10.0 \mathrm{mmol}), \mathrm{B}_{2} \operatorname{pin}_{2},(2.16 \mathrm{~g}, 8.50 \mathrm{mmol})$, HBpin $(30 \mu \mathrm{L}, 0.02 \mathrm{mmol})$, $[\operatorname{Ir}(\mathrm{COD})(\mathrm{OMe})]_{2}(16.2 \mathrm{mg}, 24.4 \mu \mathrm{mol})$, dtbpy $(1.0 \mathrm{mg}, 66 \mu \mathrm{mol})$, and THF $(10.0 \mathrm{~mL})$ were combined. The reaction mixture was heated in a sealed vessel at $80{ }^{\circ} \mathrm{C}$ for $16 \mathrm{~h}$. The reaction solution was allowed to cool to room temperature. After cooling, half of the solution was transferred to a $50 \mathrm{~mL}$ round bottom flask and was diluted with $4.0 \mathrm{~mL}$ $\mathrm{H}_{2} \mathrm{O}$. $\mathrm{NaIO}_{4}(3.21 \mathrm{~g}, 15.0 \mathrm{mmol})$ was then added. After stirring the reaction mixture for $15 \mathrm{~min}, 10 \mathrm{~mL} 1 \mathrm{M} \mathrm{HCl}(\mathrm{aq})$ was added to the reaction mixture and allowed to stir for $4 \mathrm{~h}$. The resulting mixture was extracted with EtOAc $(3 \times 25 \mathrm{~mL})$, and the organic layers were combined, washed with $\mathrm{H}_{2} \mathrm{O}(10 \mathrm{~mL})$, and finally washed with brine $(2 \times 20 \mathrm{~mL})$. The organic layer was dried over $\mathrm{MgSO}_{4}$. After filtering, the organic solvent was removed 
under vacuum and a yellow solid was obtained. The crude boronic acid was washed with hexanes and 54\% yield was obtained. ${ }^{1} \mathrm{H}$ NMR $\left(500 \mathrm{MHz}, \mathrm{CD}_{3} \mathrm{CN}\right) \delta 7.33(s, 2 \mathrm{H}), \delta$ $7.05(s, 1 \mathrm{H}) \delta 3.45(s, 6 \mathrm{H}) .{ }^{13} \mathrm{C} \mathrm{NMR}\left(500 \mathrm{MHz}\right.$, acetone- $\left.d_{6}\right): \delta 137.6, \delta 132.6, \delta 132.3$, $\delta$ 20.9. ${ }^{11} \mathrm{~B}$ NMR $\left(500 \mathrm{MHz}, \mathrm{CD}_{3} \mathrm{CN}\right): \delta 29.49$ (bs).

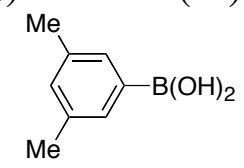

Conversion of 1,3-dichlorobenzene to 3,5-dichlorophenyl boronic acid. In a glove box, 1,3-dichlorobenzene (1.14 mL, $10.0 \mathrm{mmol}), \mathrm{B}_{2} \mathrm{pin}_{2},(2.18 \mathrm{~g}, 8.60 \mathrm{mmol})$, $[\operatorname{Ir}(\mathrm{COD})(\mathrm{OMe})]_{2}(6.2 \mathrm{mg}, 9.4 \mu \mathrm{mol})$, dtbpy $(6.0 \mathrm{mg}, 24 \mu \mathrm{mol})$, and THF $(10.0 \mathrm{~mL})$ were combined. The reaction mixture was heated in a sealed vessel at $80{ }^{\circ} \mathrm{C}$ for $16 \mathrm{~h}$. The reaction solution was allowed to cool to room temperature. After cooling, half of the solution was transferred to a $50 \mathrm{~mL}$ round bottom flask and was diluted with $4.0 \mathrm{~mL}$ $\mathrm{H}_{2} \mathrm{O}$. $\mathrm{NaIO}_{4}(3.20 \mathrm{~g}, 14.9 \mathrm{mmol})$ was then added. After stirring the reaction mixture for $15 \mathrm{~min}, 10 \mathrm{~mL} 1 \mathrm{M} \mathrm{HCl}(\mathrm{aq})$ was added to the reaction mixture and allowed to stir for $4 \mathrm{~h}$. The resulting mixture was extracted with EtOAc $(3 \times 25 \mathrm{~mL})$, and the organic layers were combined, washed with $\mathrm{H}_{2} \mathrm{O}(10 \mathrm{~mL})$, and finally washed with brine $(2 \times 20 \mathrm{~mL})$. The organic layer was dried over $\mathrm{MgSO}_{4}$. After filtering, the organic solvent was removed under vacuum and a yellow solid was obtained. The crude boronic acid was washed with hexanes and $94 \%$ yield was obtained. ${ }^{1} \mathrm{H}$ NMR $\left(500 \mathrm{MHz}, \mathrm{CD}_{3} \mathrm{CN}\right) \delta 7.69(s, 2 \mathrm{H}), \delta$ $7.52(s, 1 \mathrm{H}), \delta 3.63(s, 2 \mathrm{H}) .{ }^{13} \mathrm{C} \mathrm{NMR}\left(500 \mathrm{MHz}, \mathrm{CD}_{3} \mathrm{CN}\right): \delta 135.1, \delta 133.0, \delta 130.7$. ${ }^{11} \mathrm{~B}$ NMR (500 MHz, $\left.\mathrm{CD}_{3} \mathrm{CN}\right): \delta 28.1$ (bs).

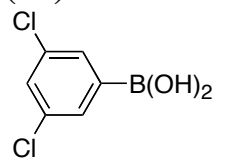

\section{Conversion of 1-methoxy-3-trifluoromethylbenzene to 3-methoxy-5- \\ trifluoromethylphenyl boronic acid. In a glove box, 1-methoxy-3-} trifluoromethylbenzene $(1.45 \mathrm{~mL}, 10.00 \mathrm{mmol}), \mathrm{B}_{2}$ pin $_{2},(2.23 \mathrm{~g}, 8.78 \mathrm{mmol})$, $[\mathrm{Ir}(\mathrm{COD})(\mathrm{OMe})]_{2}(6.4 \mathrm{mg}, 10 \mu \mathrm{mol})$, dtbpy $(5.7 \mathrm{mg}, 21 \mu \mathrm{mol})$, and THF $(10.0 \mathrm{~mL})$ were combined. The reaction mixture was heated in a sealed vessel at $80{ }^{\circ} \mathrm{C}$ for $16 \mathrm{~h}$. The reaction solution was allowed to cool to room temperature. After cooling, half of the solution was transferred to a $50 \mathrm{~mL}$ round bottom flask and was diluted with $4.0 \mathrm{~mL}$ $\mathrm{H}_{2} \mathrm{O} . \mathrm{NaIO}_{4}(3.17 \mathrm{~g}, 14.8 \mathrm{mmol})$ was added. After stirring the reaction mixture for 15 min, $10.0 \mathrm{~mL} 1 \mathrm{M} \mathrm{HCl}$ (aq) was added to the reaction mixture and allowed to stir for $4 \mathrm{~h}$. The resulting mixture was extracted with EtOAc $(3 \times 25 \mathrm{~mL})$, and the organic layers were combined, washed with $\mathrm{H}_{2} \mathrm{O}(10 \mathrm{~mL})$, and finally washed with brine $(2 \times 20 \mathrm{~mL})$. The organic layer was dried over $\mathrm{MgSO}_{4}$. After filtering, the organic solvent was removed under vacuum and a yellow solid was obtained. The crude boronic acid was washed with hexanes and $85 \%$ yield was obtained. ${ }^{1} \mathrm{H}$ NMR $\left(500 \mathrm{MHz}, \mathrm{CD}_{3} \mathrm{CN}\right) \delta 7.60(s, 2 \mathrm{H}), \delta$ $7.51(s, 1 \mathrm{H}) \delta 7.51(s, 1 \mathrm{H}), \delta 3.80(s, 2 \mathrm{H}) .{ }^{13} \mathrm{C} \mathrm{NMR}\left(500 \mathrm{MHz}, \mathrm{CD}_{3} \mathrm{CN}\right): \delta 160.2, \delta$ 123.5, $\delta$ 123.1, $\delta 113.3, \delta 55.9 .{ }^{11} \mathrm{~B} \mathrm{NMR}\left(500 \mathrm{MHz}, \mathrm{CD}_{3} \mathrm{CN}\right): \delta 28.7$ (bs). 


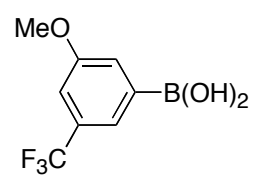

Conversion of 1-methoxycarbonyl-3-methylbenzene to 3-methoxycarbonyl-5-

methylphenyl boronic acid. In a glove box, 1-methoxycarbonyl-3-methylbenzene (1.42 $\mathrm{mL}, 10.0 \mathrm{mmol}), \mathrm{B}_{2} \mathrm{pin}_{2},(2.16 \mathrm{~g}, 8.52 \mathrm{mmol})$, [Ir(COD)(OMe) $]_{2}(6.4 \mathrm{mg}, 9.6 \mu \mathrm{mol})$, dtbpy $(5.4 \mathrm{mg}, 20 \mu \mathrm{mol})$, and THF $(10.0 \mathrm{~mL})$ were combined. The reaction mixture was heated in a sealed vessel at $80{ }^{\circ} \mathrm{C}$ for $16 \mathrm{~h}$. The reaction solution was allowed to cool to room temperature. After cooling, half of the solution was transferred to a $50 \mathrm{~mL}$ round bottom flask and was diluted with $4.0 \mathrm{~mL} \mathrm{H}_{2} \mathrm{O} . \mathrm{NaIO}_{4}(3.17 \mathrm{~g}, 14.8 \mathrm{mmol})$ was added. After stirring the reaction mixture for $15 \mathrm{~min}, 10.0 \mathrm{~mL} 1 \mathrm{M} \mathrm{HCl} \mathrm{(aq)} \mathrm{was} \mathrm{added} \mathrm{to} \mathrm{the}$ reaction mixture and allowed to stir for $4 \mathrm{~h}$. The resulting mixture was extracted with EtOAc $(3 \times 25 \mathrm{~mL})$, and the organic layers were combined, washed with $\mathrm{H}_{2} \mathrm{O}(10 \mathrm{~mL})$, and finally washed with brine $(2 \times 20 \mathrm{~mL})$. The organic layer was dried over $\mathrm{MgSO}_{4}$. After filtering, the organic solvent was removed under vacuum and a yellow solid was obtained. The crude boronic acid was washed with hexanes and $85 \%$ yield was obtained. ${ }^{1} \mathrm{H}$ NMR $\left(500 \mathrm{MHz}, \mathrm{CD}_{3} \mathrm{CN}\right) \delta 7.60(s, 2 \mathrm{H}), \delta 7.51(s, 1 \mathrm{H}), \delta 3.82(s, 3 \mathrm{H}), \delta 3.48(s, 3$ $\mathrm{H}) .{ }^{13} \mathrm{C}$ NMR $\left(500 \mathrm{MHz}, \mathrm{CD}_{3} \mathrm{CN}\right): \delta 167.9, \delta 138.5, \delta 132.9, \delta 132.5, \delta 130.4, \delta 52.4, \delta$ 21.1. ${ }^{11} \mathrm{~B} \mathrm{NMR}\left(500 \mathrm{MHz}, \mathrm{CD}_{3} \mathrm{CN}\right): \delta 28.9$ (bs).

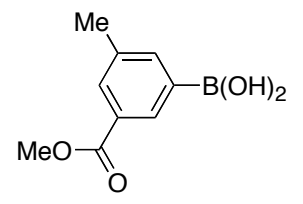

\section{Conversion of 1-chloro-3-trifluoromethylbenzene to 3-chloro-5-}

trifluoromethylphenyl boronic acid. In a glove box, 1-chloro-3-trifluoromethylbenzene (1.23 mL, $10.0 \mathrm{mmol}), \mathrm{B}_{2} \mathrm{pin}_{2},(2.23 \mathrm{~g}, 8.79 \mathrm{mmol})$, [Ir(COD)(OMe) $]_{2}(6.8 \mathrm{mg}, 10 \mu \mathrm{mol})$, dtbpy $(7.0 \mathrm{mg}, 26 \mu \mathrm{mol})$, and THF $(10.0 \mathrm{~mL})$ were combined. The reaction mixture was heated in a sealed vessel at $80{ }^{\circ} \mathrm{C}$ for $16 \mathrm{~h}$. The reaction solution was allowed to cool to room temperature. After cooling, half of the solution was transferred to a $50 \mathrm{~mL}$ round bottom flask and was diluted with $4.0 \mathrm{~mL} \mathrm{H} \mathrm{H}_{2} \mathrm{O} . \mathrm{NaIO}_{4}(3.23 \mathrm{~g}, 15.1 \mathrm{mmol})$ was added. After stirring the reaction mixture for $15 \mathrm{~min}, 10.0 \mathrm{~mL} 1 \mathrm{M} \mathrm{HCl} \mathrm{(aq)} \mathrm{was} \mathrm{added} \mathrm{to} \mathrm{the}$ reaction mixture and allowed to stir for $4 \mathrm{~h}$. The resulting mixture was extracted with EtOAc $(3 \times 25 \mathrm{~mL})$, and the organic layers were combined, washed with $\mathrm{H}_{2} \mathrm{O}(10 \mathrm{~mL})$, and finally washed with brine $(2 \times 20 \mathrm{~mL})$. The organic layer was dried over $\mathrm{MgSO}_{4}$. After filtering, the organic solvent was removed under vacuum and a yellow solid was obtained. The crude boronic acid was washed with hexanes and $90 \%$ yield was obtained.. ${ }^{1} \mathrm{H}$ NMR (500 MHz, CD $\left.{ }_{3} \mathrm{CN}\right) \delta 7.98$ (s, $\left.1 \mathrm{H}\right), \delta 7.26$ (s, $\left.1 \mathrm{H}\right), \delta 7.04(\mathrm{~s}, 1 \mathrm{H}), \delta$ $3.81(\mathrm{~s}, 3 \mathrm{H}) .{ }^{13} \mathrm{C} \mathrm{NMR}\left(500 \mathrm{MHz}, \mathrm{CD}_{3} \mathrm{CN}\right): \delta 160.5, \delta 109.8, \delta 98.5, \delta 54.9 .{ }^{11} \mathrm{~B} \mathrm{NMR}$ $\left(500 \mathrm{MHz}, \mathrm{CD}_{3} \mathrm{CN}\right): \delta 28.6(\mathrm{bs})$.

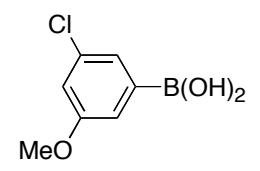




\section{Conversion of 1-chloro-3-methylbenzene to 3-chloro-5-trifluoromethylphenyl} boronic acid. In a glove box, 1-chloro-3-methylbenzene $(1.18 \mathrm{~mL}, 10.0 \mathrm{mmol}), \mathrm{B}_{2} \mathrm{pin}_{2}$, (2.16 g, $8.51 \mathrm{mmol}),[\operatorname{Ir}(\mathrm{COD})(\mathrm{OMe})]_{2}(6.7 \mathrm{mg}, 10 \mu \mathrm{mol})$, dtbpy $(5.6 \mathrm{mg}, 21 \mu \mathrm{mol})$, and THF $(10.0 \mathrm{~mL})$ were combined. The reaction mixture was heated in a sealed vessel at 80 ${ }^{\circ} \mathrm{C}$ for $16 \mathrm{~h}$. The reaction solution was allowed to cool to room temperature. After cooling, half of the solution was transferred to a $50 \mathrm{~mL}$ round bottom flask and was diluted with $4.0 \mathrm{~mL} \mathrm{H}_{2} \mathrm{O}$. $\mathrm{NaIO}_{4}(3.16 \mathrm{~g}, 14.8 \mathrm{mmol})$ was added. After stirring the reaction mixture for $15 \mathrm{~min}, 10.0 \mathrm{~mL} 1 \mathrm{M} \mathrm{HCl}(\mathrm{aq})$ was added to the reaction mixture and allowed to stir for $4 \mathrm{~h}$. The resulting mixture was extracted with EtOAc ( $3 \times 25 \mathrm{~mL})$, and the organic layers were combined, washed with $\mathrm{H}_{2} \mathrm{O}(10 \mathrm{~mL})$, and finally washed with brine $(2 \times 20 \mathrm{~mL})$. The organic layer was dried over $\mathrm{MgSO}_{4}$. After filtering, the organic solvent was removed under vacuum and a yellow solid was obtained. The crude boronic acid was washed with hexanes and $89 \%$ yield was obtained.. ${ }^{1} \mathrm{H}$ NMR $(500 \mathrm{MHz}$, $\left.\mathrm{CD}_{3} \mathrm{CN}\right) \delta 7.98(\mathrm{~s}, 1 \mathrm{H}), \delta 7.26(\mathrm{~s}, 1 \mathrm{H}), \delta 7.04(\mathrm{~s}, 1 \mathrm{H}), \delta 3.81(\mathrm{~s}, 3 \mathrm{H}) .{ }^{13} \mathrm{C} \mathrm{NMR}$ $\left(500 \mathrm{MHz}, \mathrm{CD}_{3} \mathrm{CN}\right): \delta 140.5, \delta 134.0, \delta 133.9, \delta 131.6, \delta 131.4, \delta 21.0 .{ }^{11} \mathrm{~B}$ NMR $(500$ $\mathrm{MHz}, \mathrm{CD}_{3} \mathrm{CN}$ ): $\delta 28.6$ (bs).

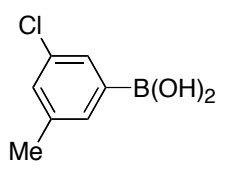

Conversion of 1,3-(trfluoromethyl)benzene to potassium (3,5- trfluoromethyl phenyl)trifluoroborate. In a glove box, 1,3-(trifluoromethyl)benzene (1.55 mL, 10.0 $\mathrm{mmol}), \mathrm{B}_{2} \mathrm{pin}_{2}$, (3.17 g, $\left.14.8 \mathrm{mmol}\right),[\operatorname{Ir}(\mathrm{COD})(\mathrm{OMe})]_{2}(6.1 \mathrm{mg}, 9.2 \mu \mathrm{mol})$, dtbpy $(5.3$ $\mathrm{mg}, 20 \mu \mathrm{mol})$, and THF $(10.0 \mathrm{~mL})$ were combined. The reaction mixture was heated in a sealed vessel at $80{ }^{\circ} \mathrm{C}$ for $16 \mathrm{~h}$. The reaction solution was allowed to cool to room temperature. After cooling, half of the solution was transferred to a $50 \mathrm{~mL}$ round bottom flask and was diluted with $4.0 \mathrm{~mL} \mathrm{H}_{2} \mathrm{O} . \mathrm{NaIO}_{4}(3.17 \mathrm{~g}, 14.8 \mathrm{mmol})$ was added. After stirring the reaction mixture for $15 \mathrm{~min}, 10.0 \mathrm{~mL} 1 \mathrm{M} \mathrm{HCl}(\mathrm{aq})$ was added to the reaction mixture and allowed to stir for $4 \mathrm{~h}$. The resulting mixture was extracted with EtOAc $(3 \mathrm{x}$ $25 \mathrm{~mL})$, and the organic layers were combined, washed with $\mathrm{H}_{2} \mathrm{O}(10 \mathrm{~mL})$, and finally washed with brine $(2 \times 20 \mathrm{~mL})$. The organic layer was dried over $\mathrm{MgSO}_{4}$. After filtering, the organic solvent was removed under vacuum and a yellow solid was obtained. The crude boronic acid was washed with hexanes and $81 \%$ yield was obtained.. ${ }^{1} \mathrm{H}$ NMR (500 MHz, CD $\left.{ }_{3} \mathrm{CN}\right) \delta 7.98$ (s, $\left.1 \mathrm{H}\right), \delta 7.26$ (s, $\left.1 \mathrm{H}\right), \delta 7.04(\mathrm{~s}, 1 \mathrm{H}), \delta$ $3.81(\mathrm{~s}, 3 \mathrm{H}) .{ }^{11} \mathrm{~B} \mathrm{NMR}\left(500 \mathrm{MHz}, \mathrm{CD}_{3} \mathrm{CN}\right): \delta 28.6(\mathrm{bs})$<smiles>Oc1cc(C(F)(F)F)cc(C(F)(F)F)c1</smiles>

\section{REFERENCES}

1. Herde, J. L.; Lambert, J. C.; Senoff, C. V., Inorg. Syn. 1974, 15, 18. 

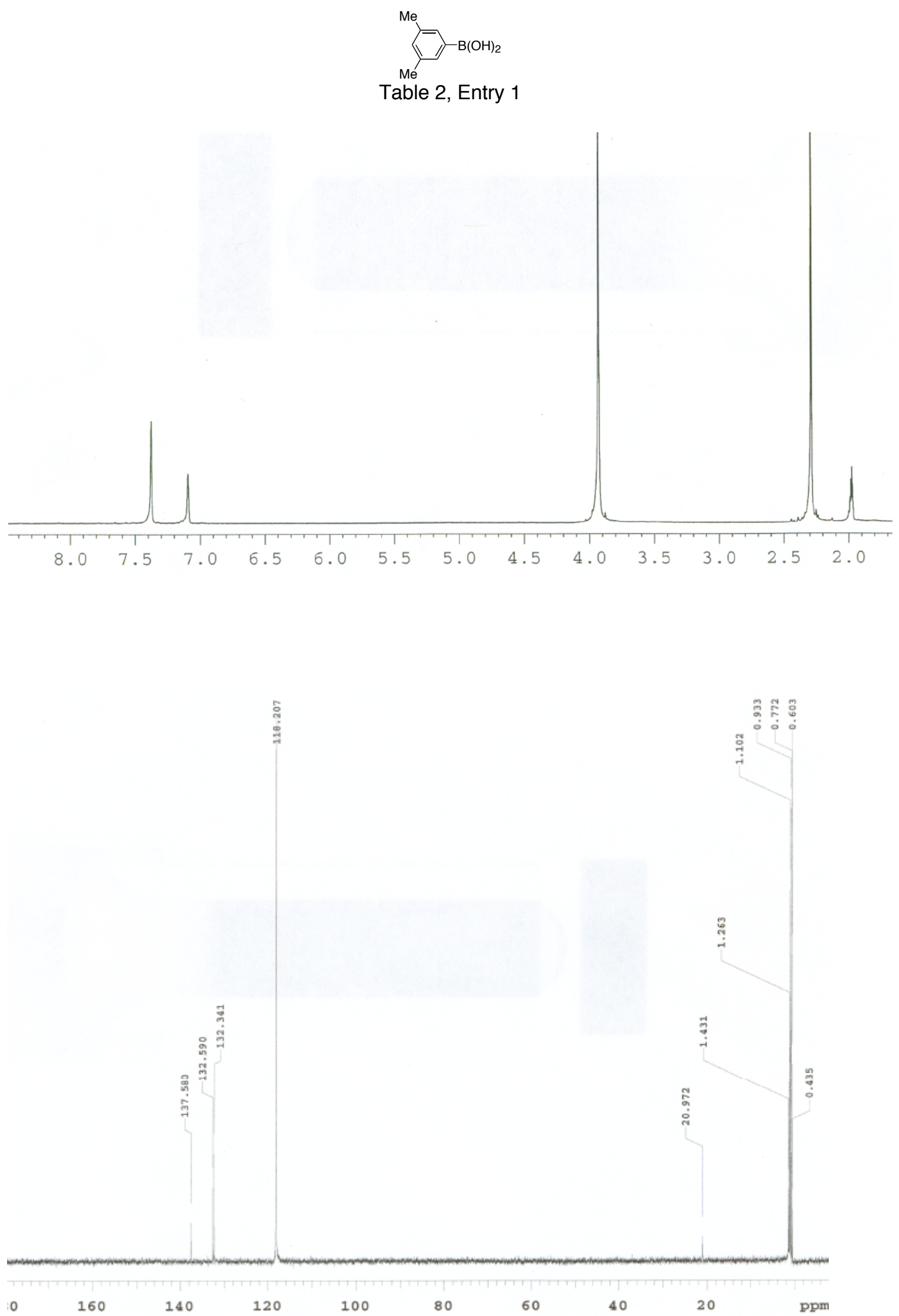


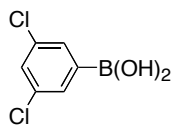

Table 2, Entry 2
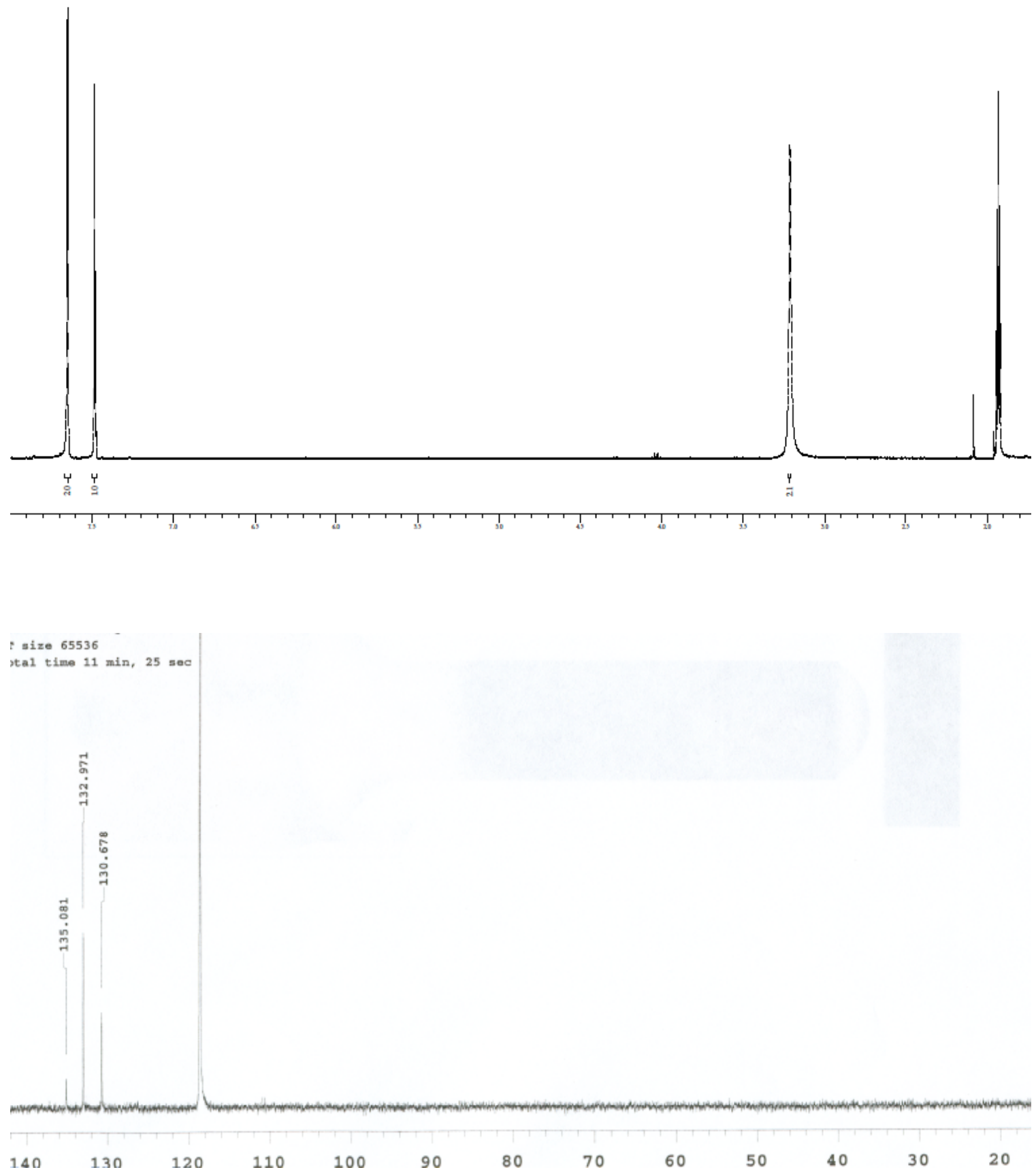


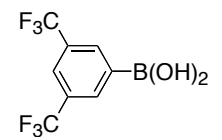

Table 2, Entry 3
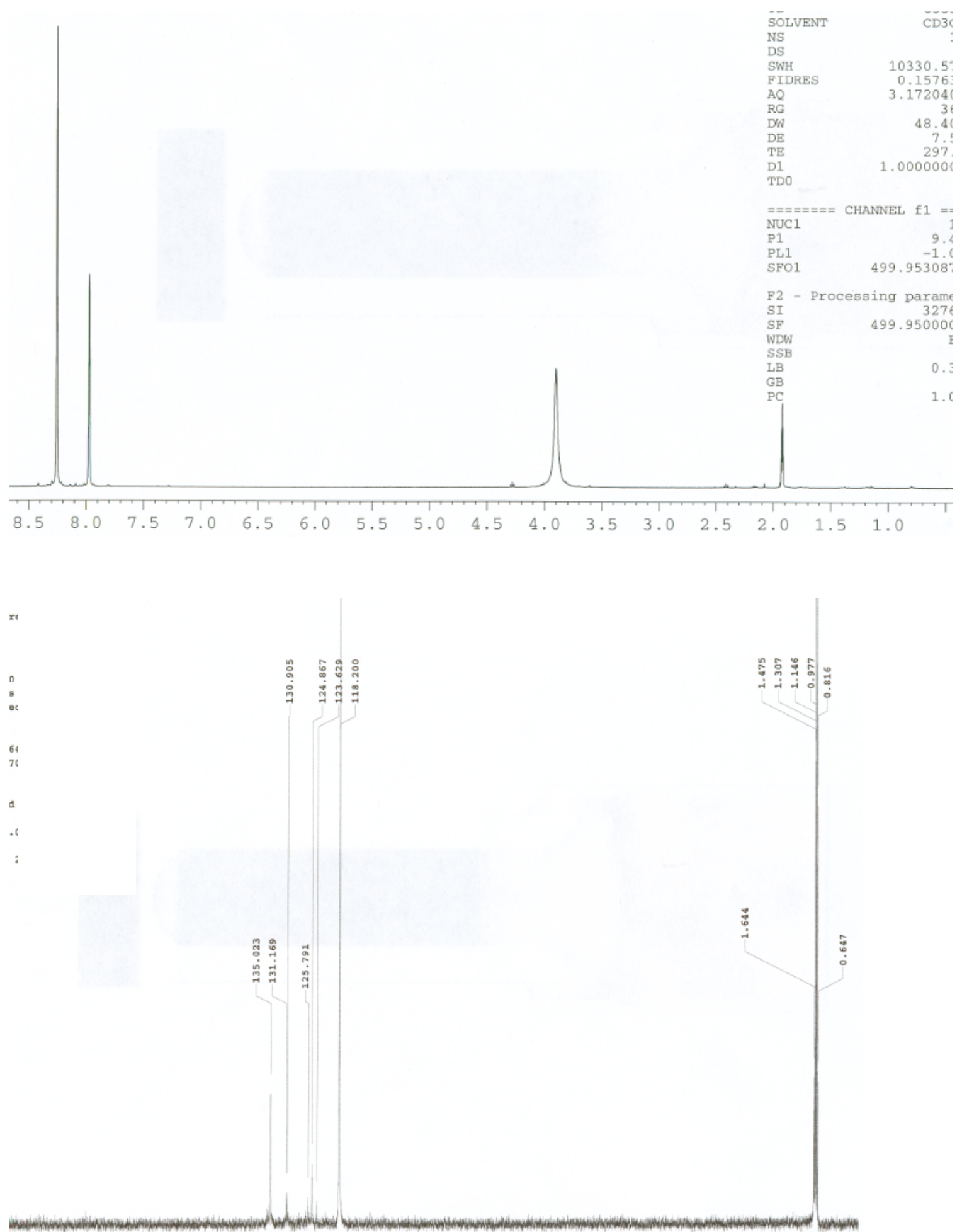

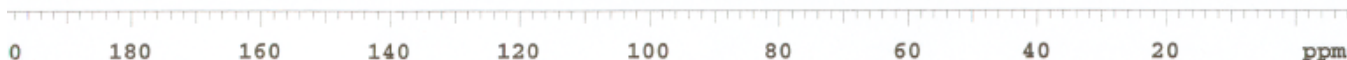




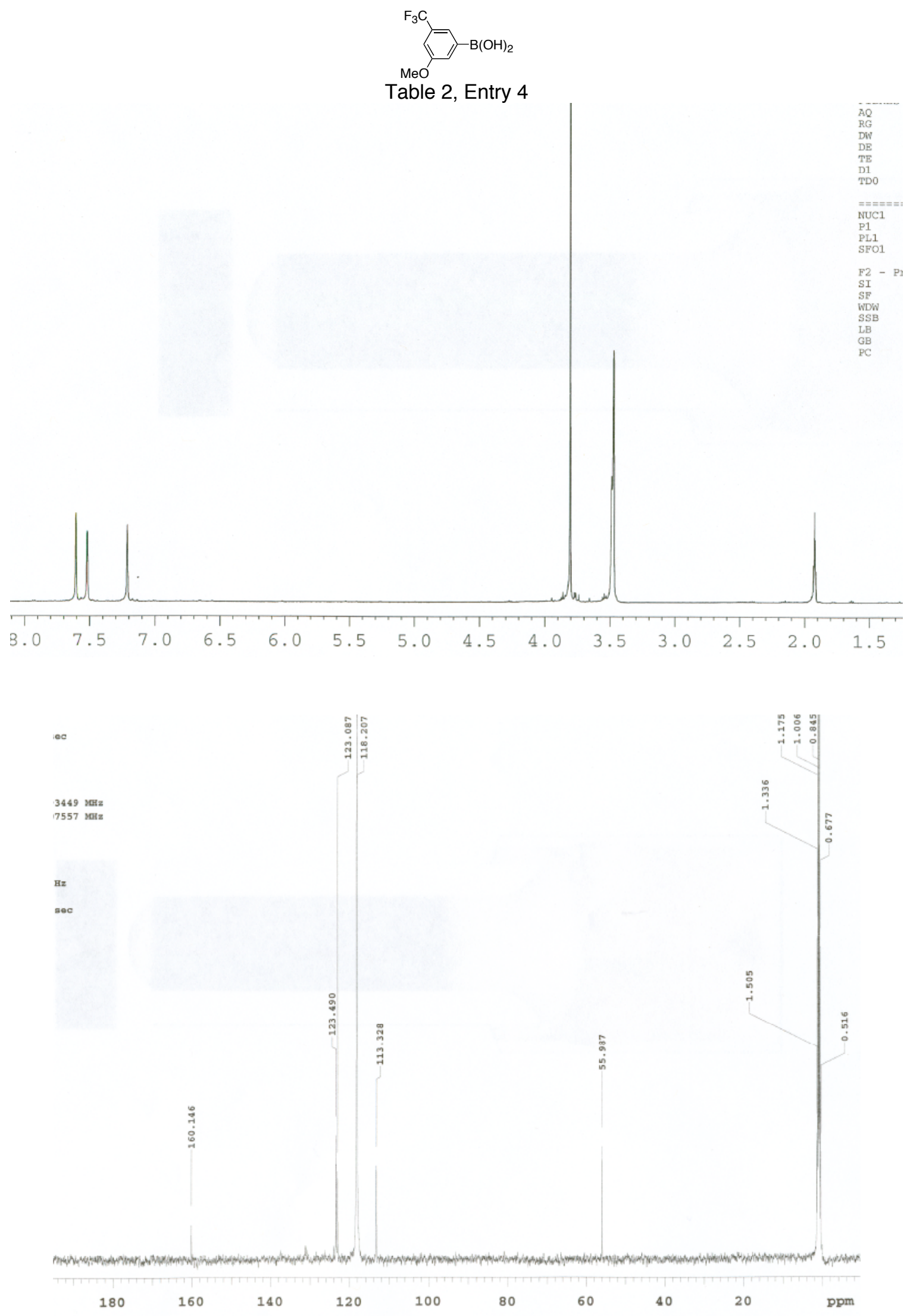




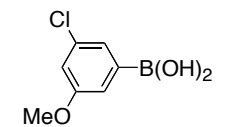

Table 2, Entry 5
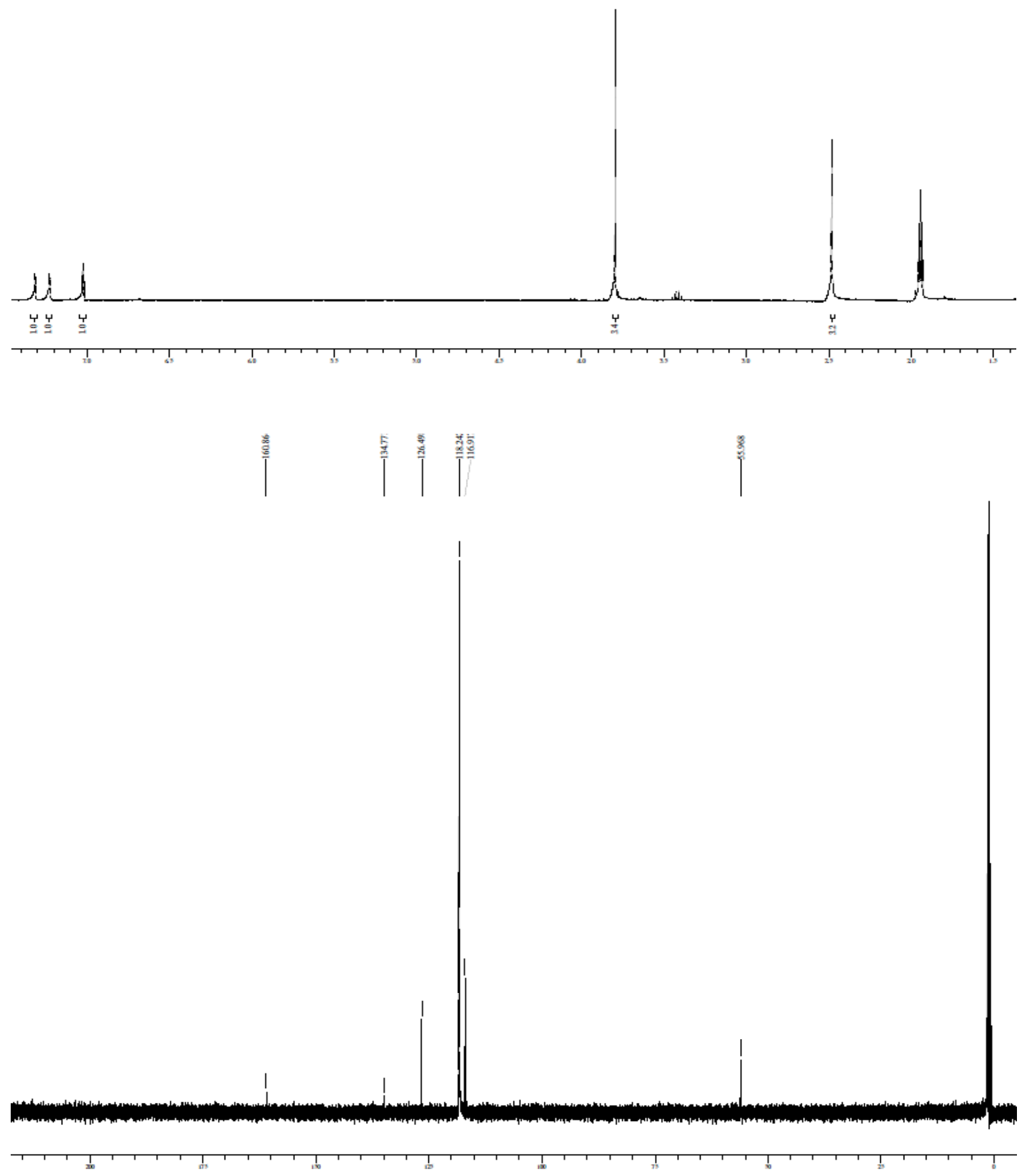
$\mathrm{Cl}$<smiles>Cc1cccc([Sb](=O)O)c1</smiles>

able 2, Entry 6
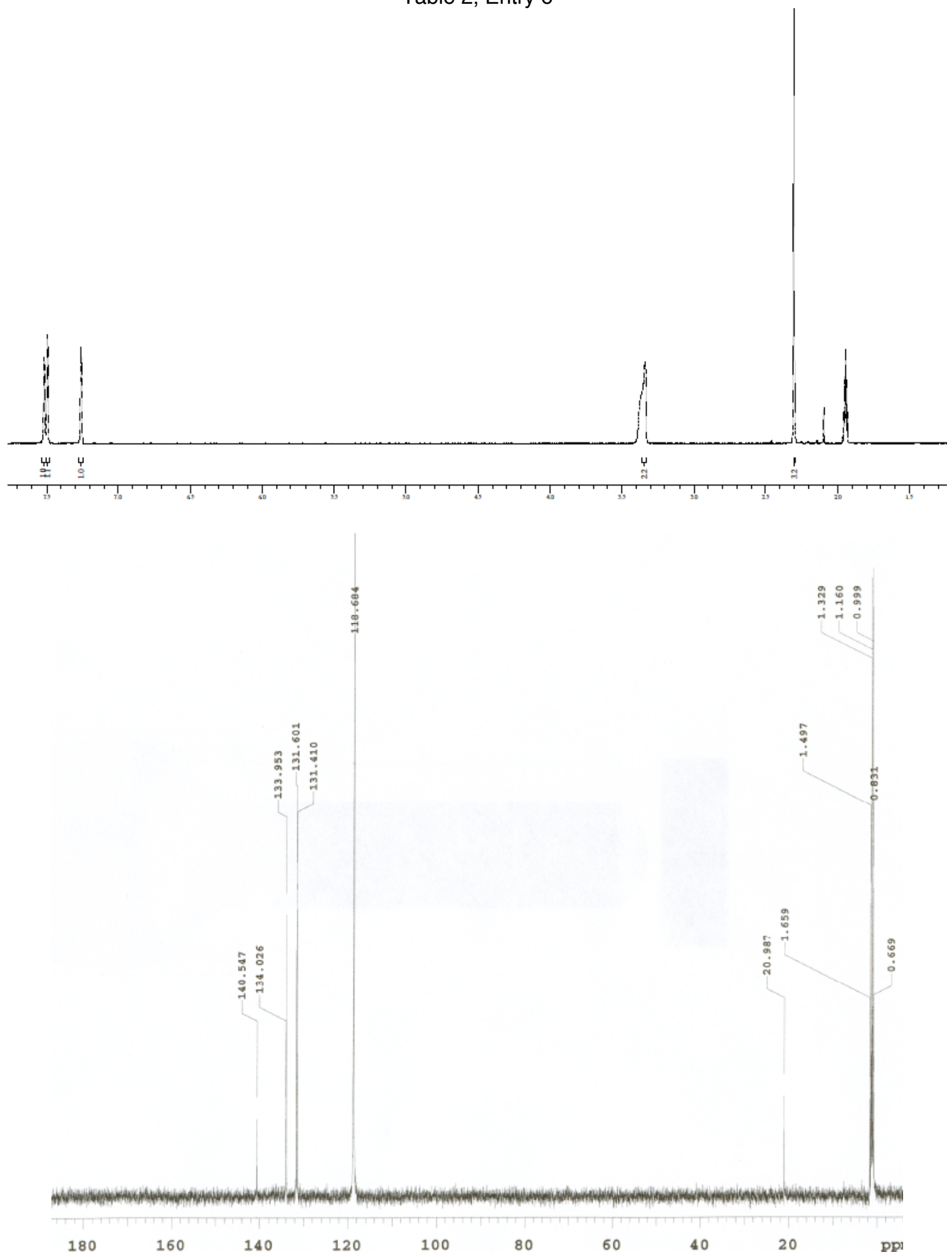


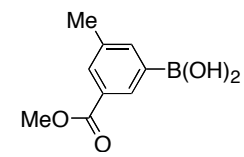

Table 2, Entry 7
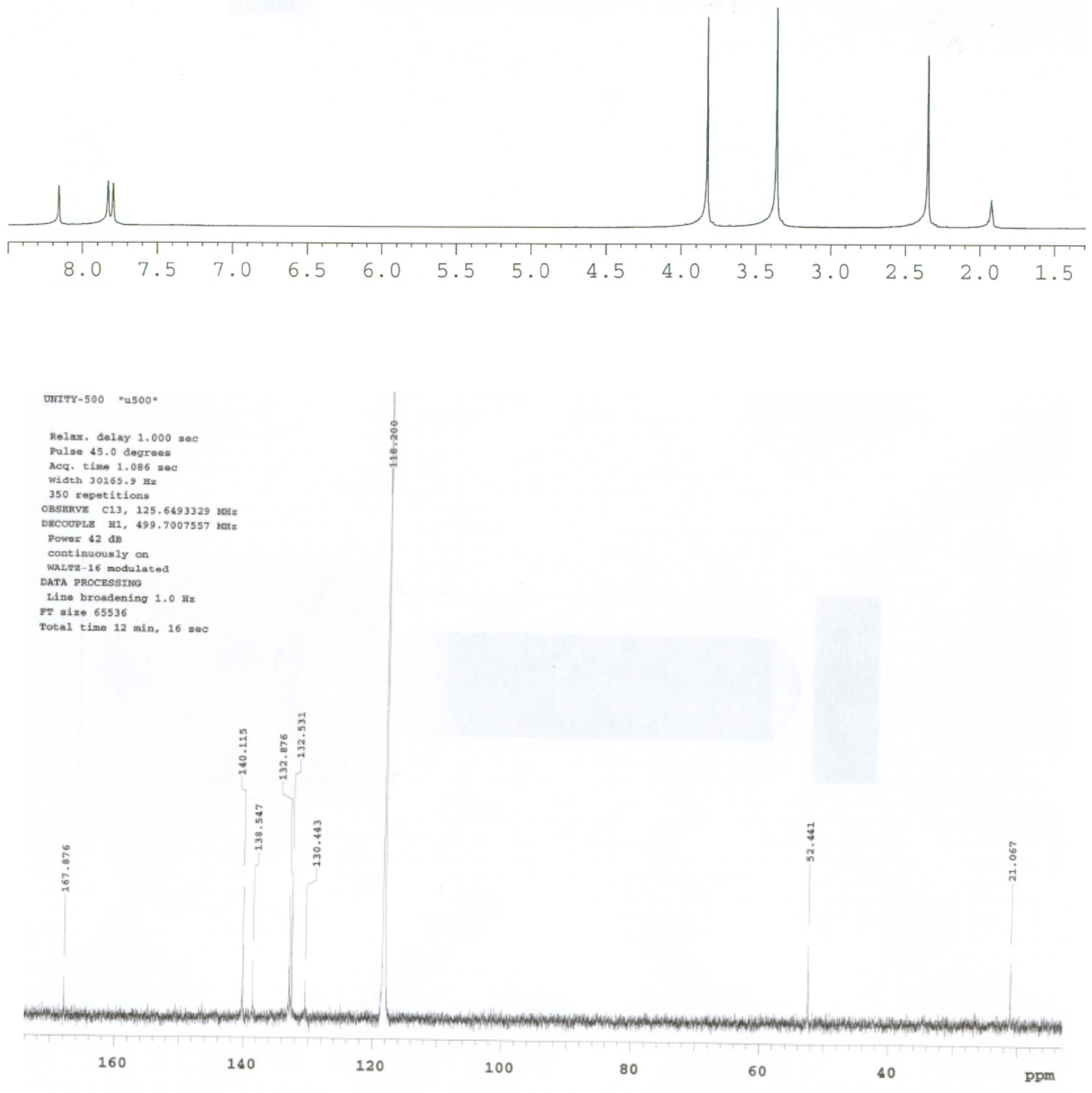


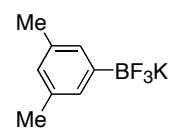

Table 3, Entry 1
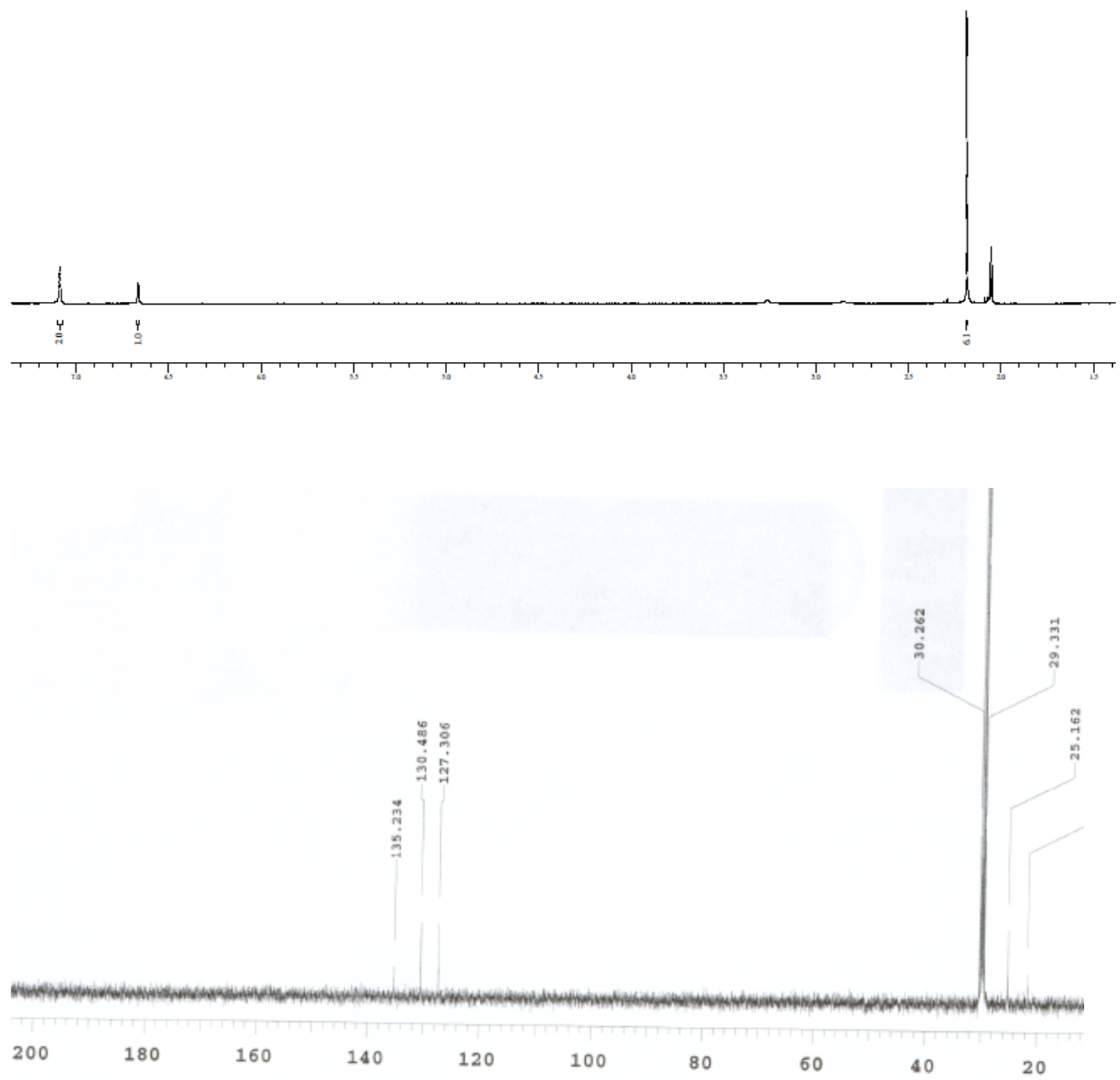


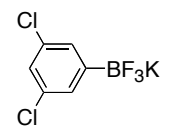

Table 3, Entry 2
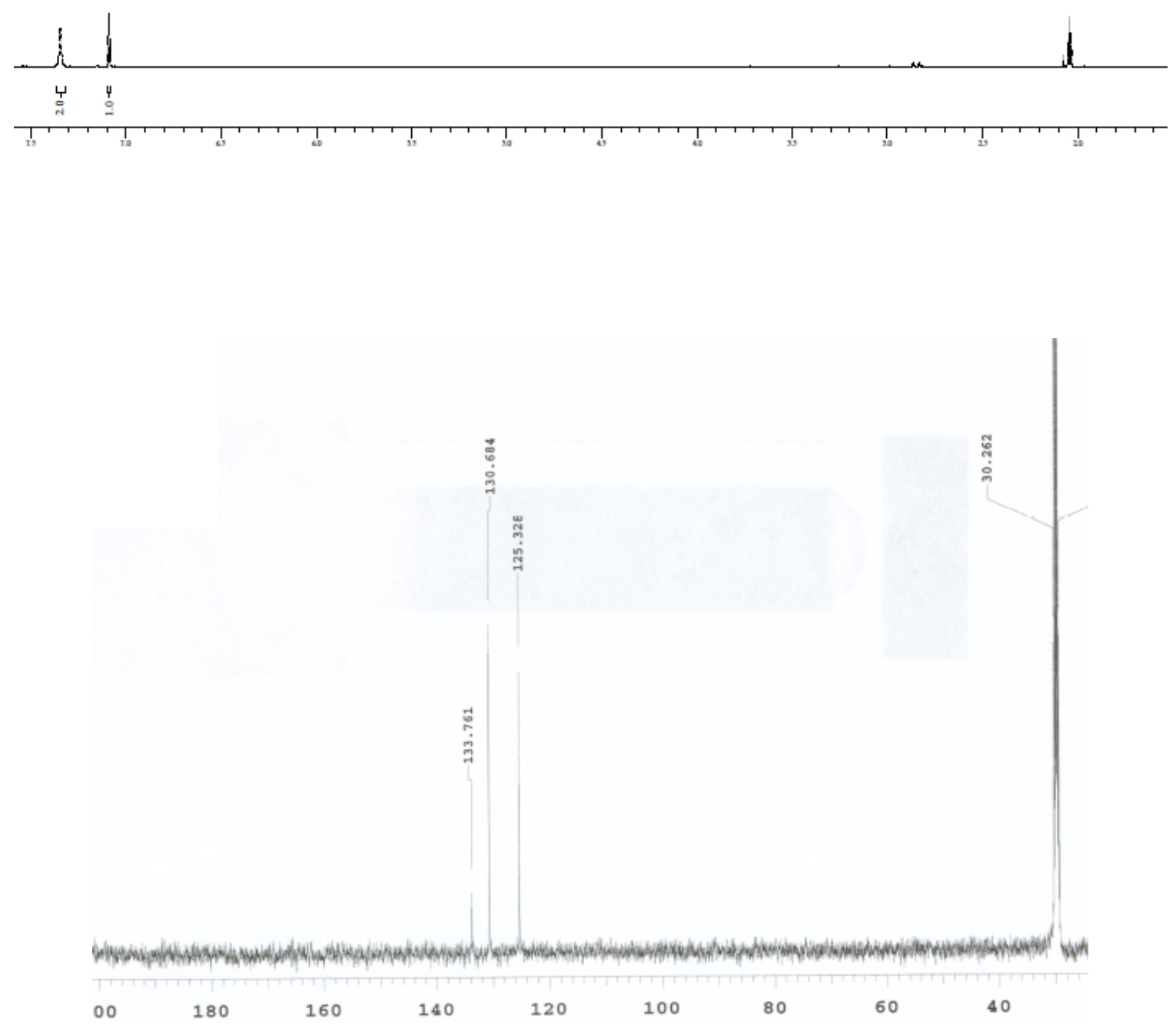


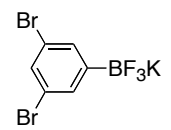

Table 3, Entry 3
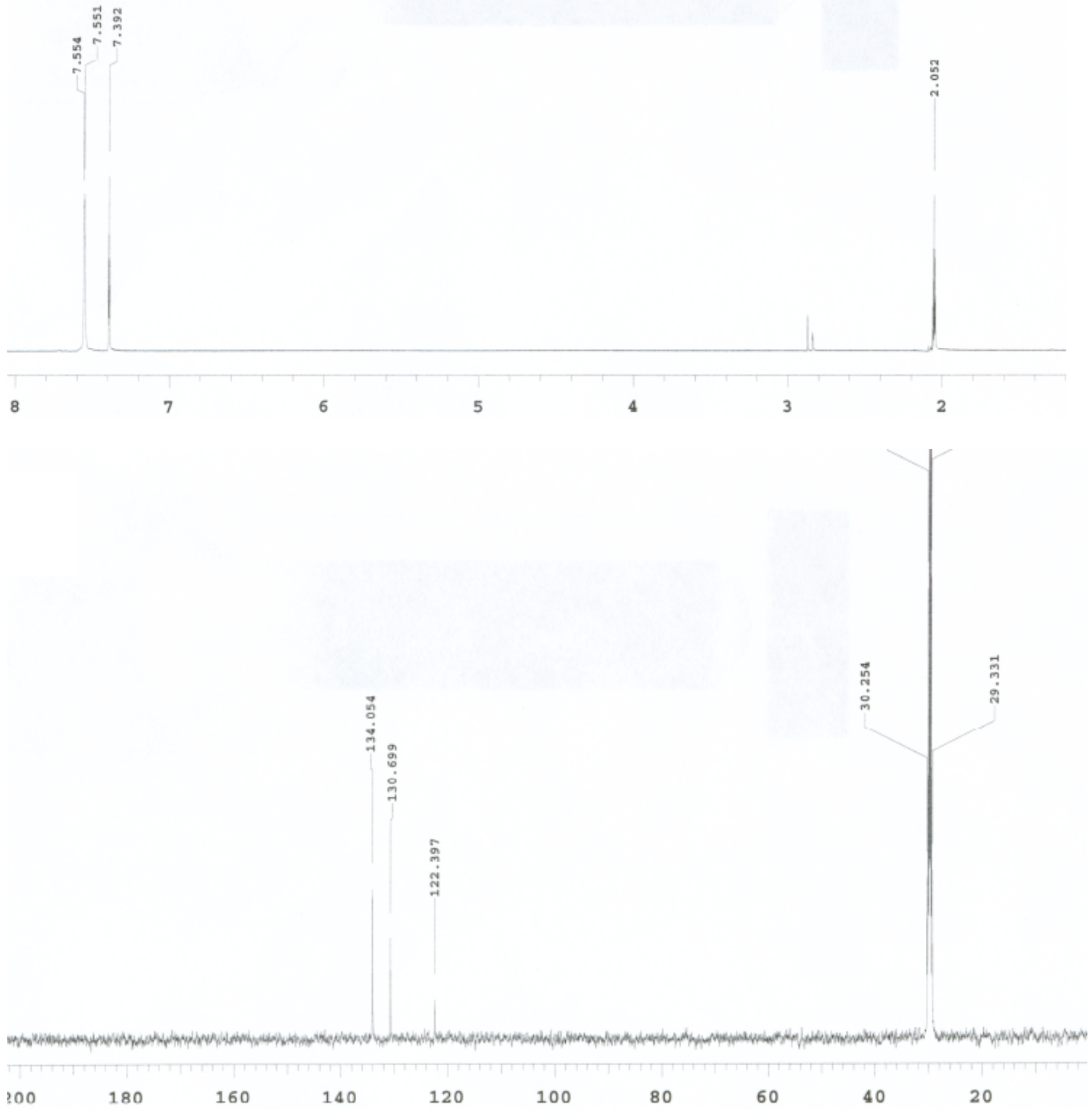


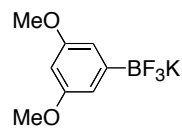

Table 3, Entry 4

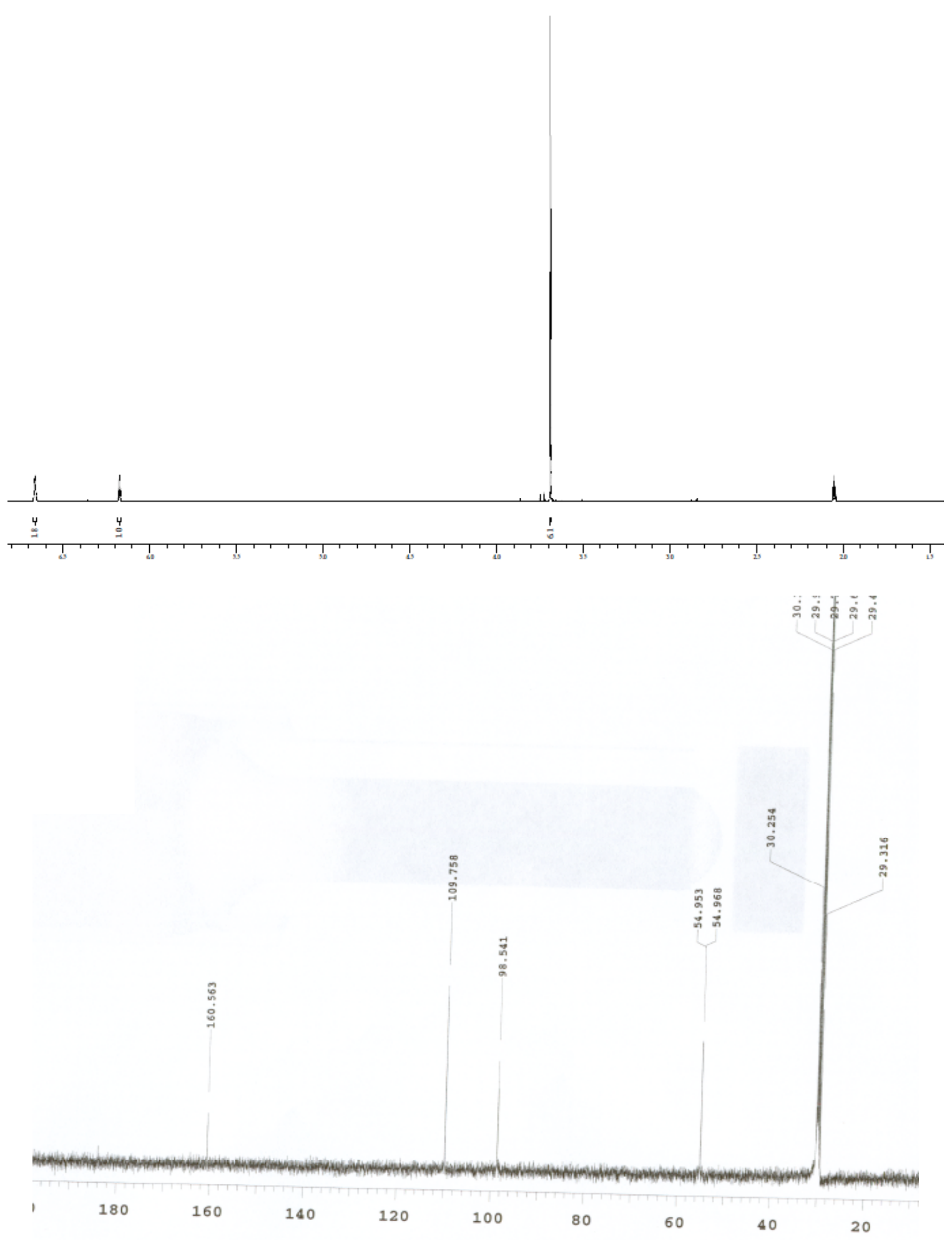




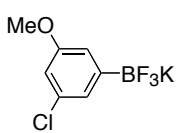

Table 3, Entry 5

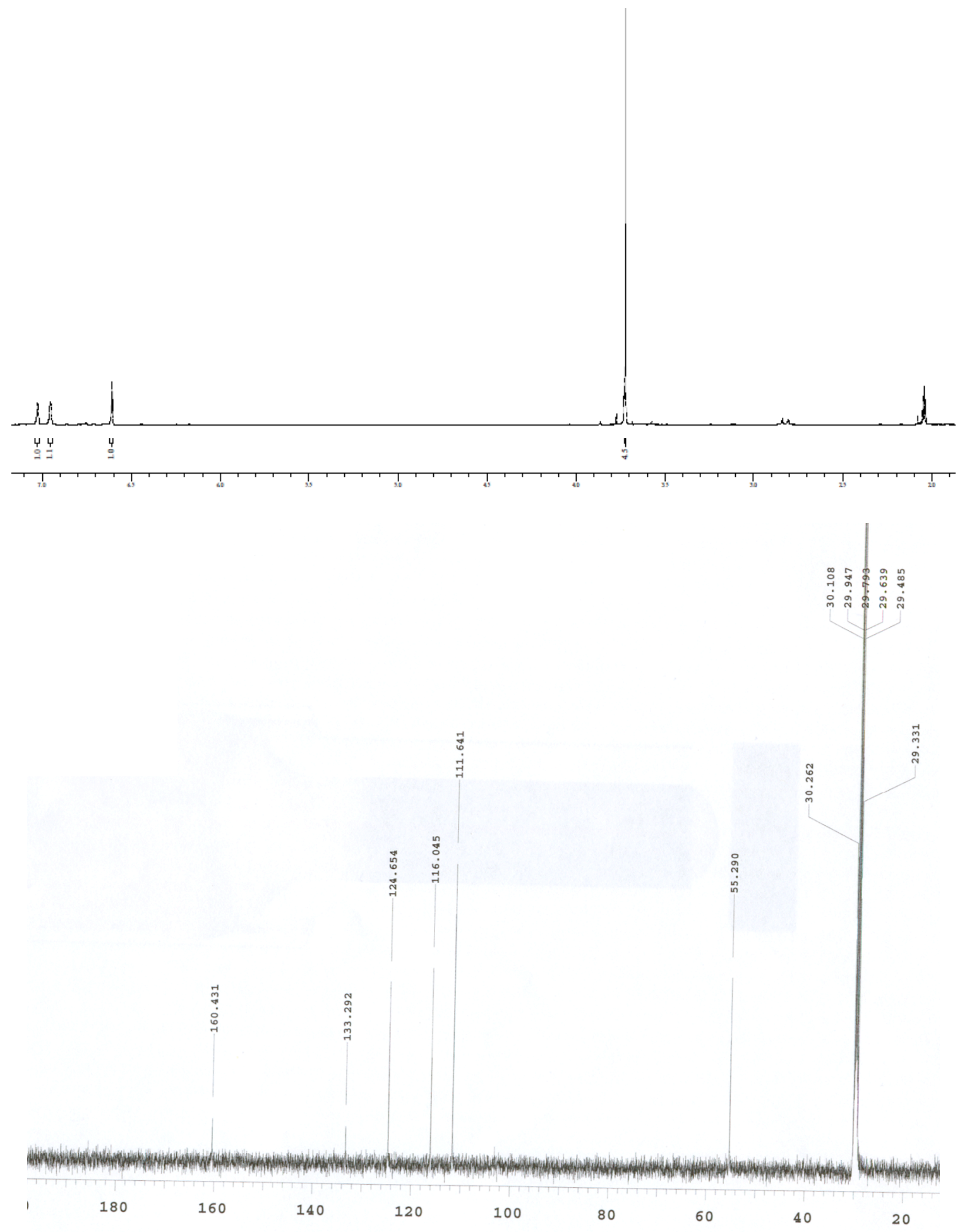




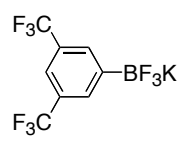

Table 3, Entry 6

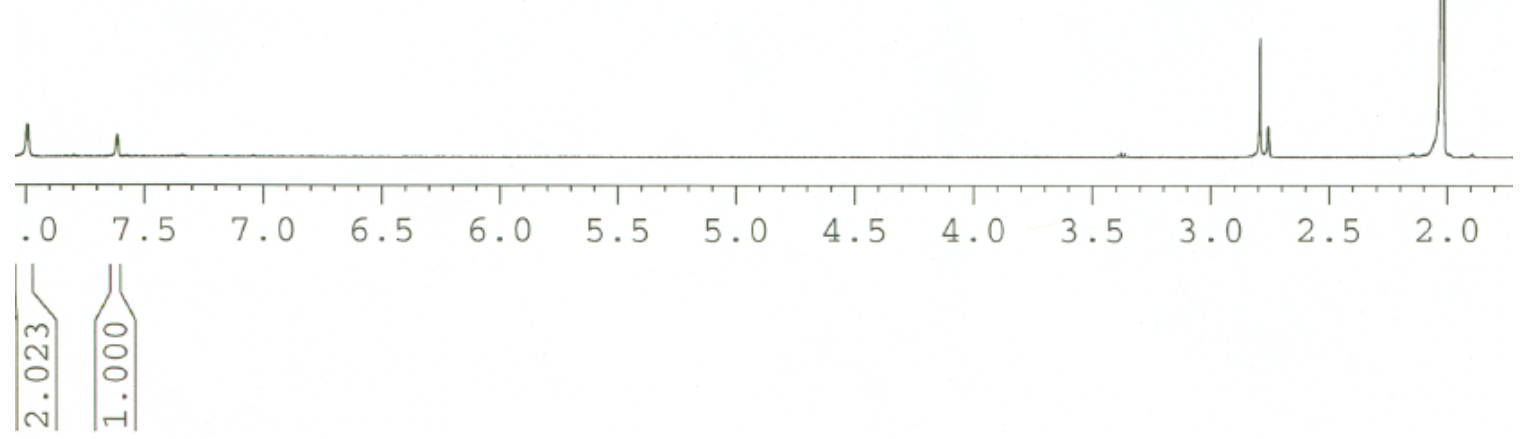

ed

$1.0 \mathrm{~Hz}$

$58 \mathrm{sec}$
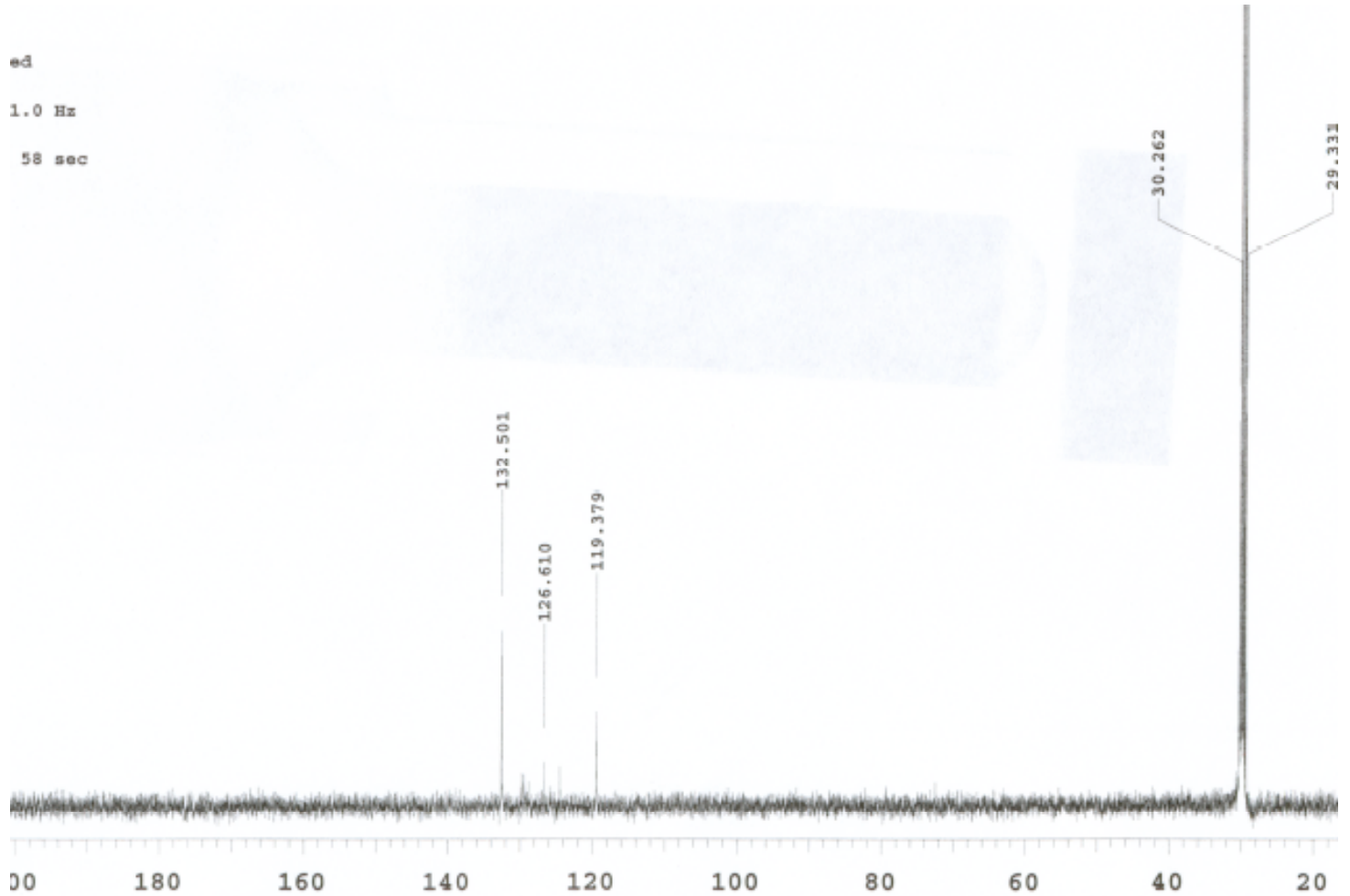


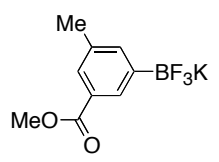

Table 3, Entry 7
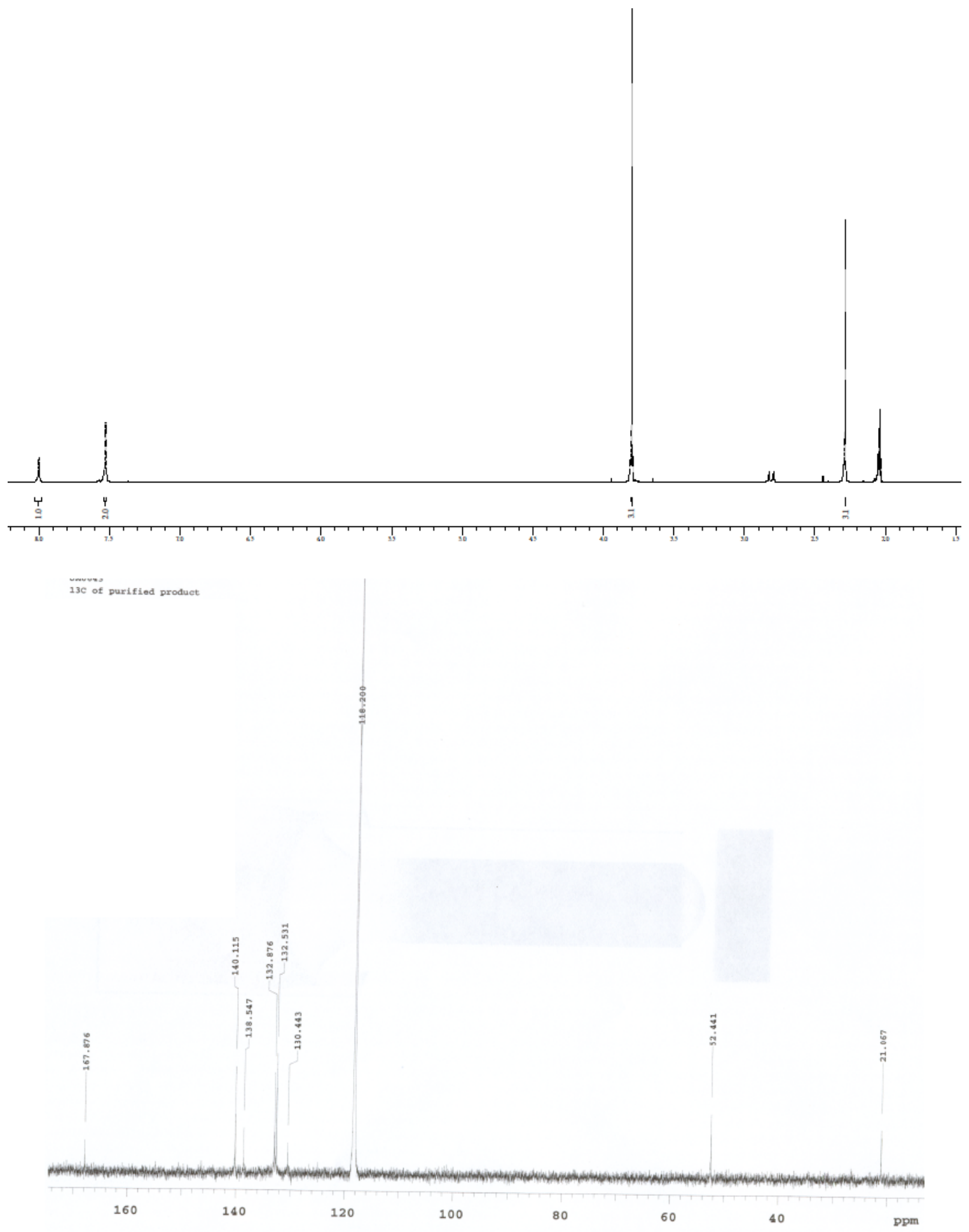


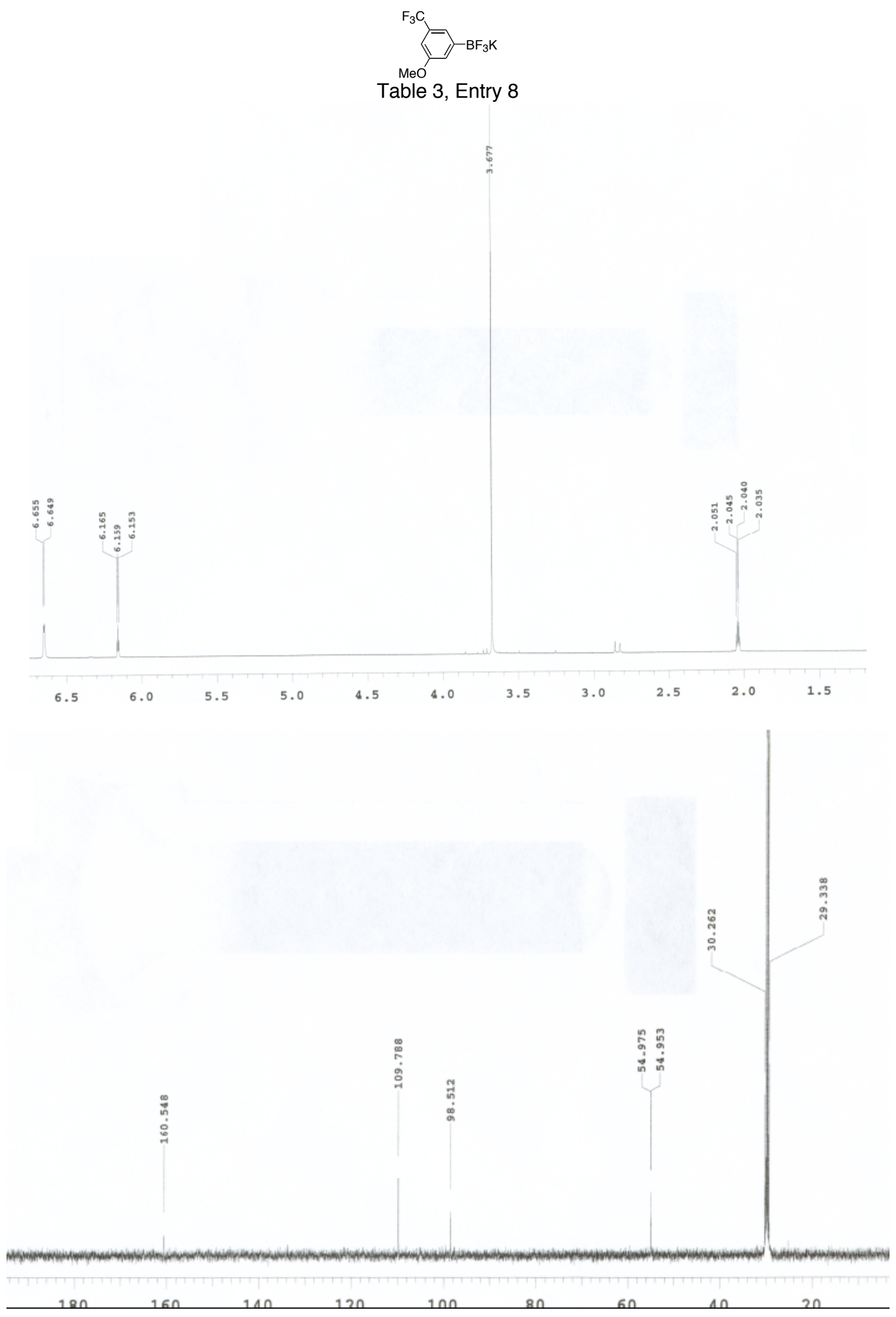




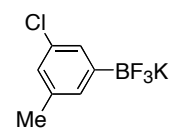

Table 3, Entry 9
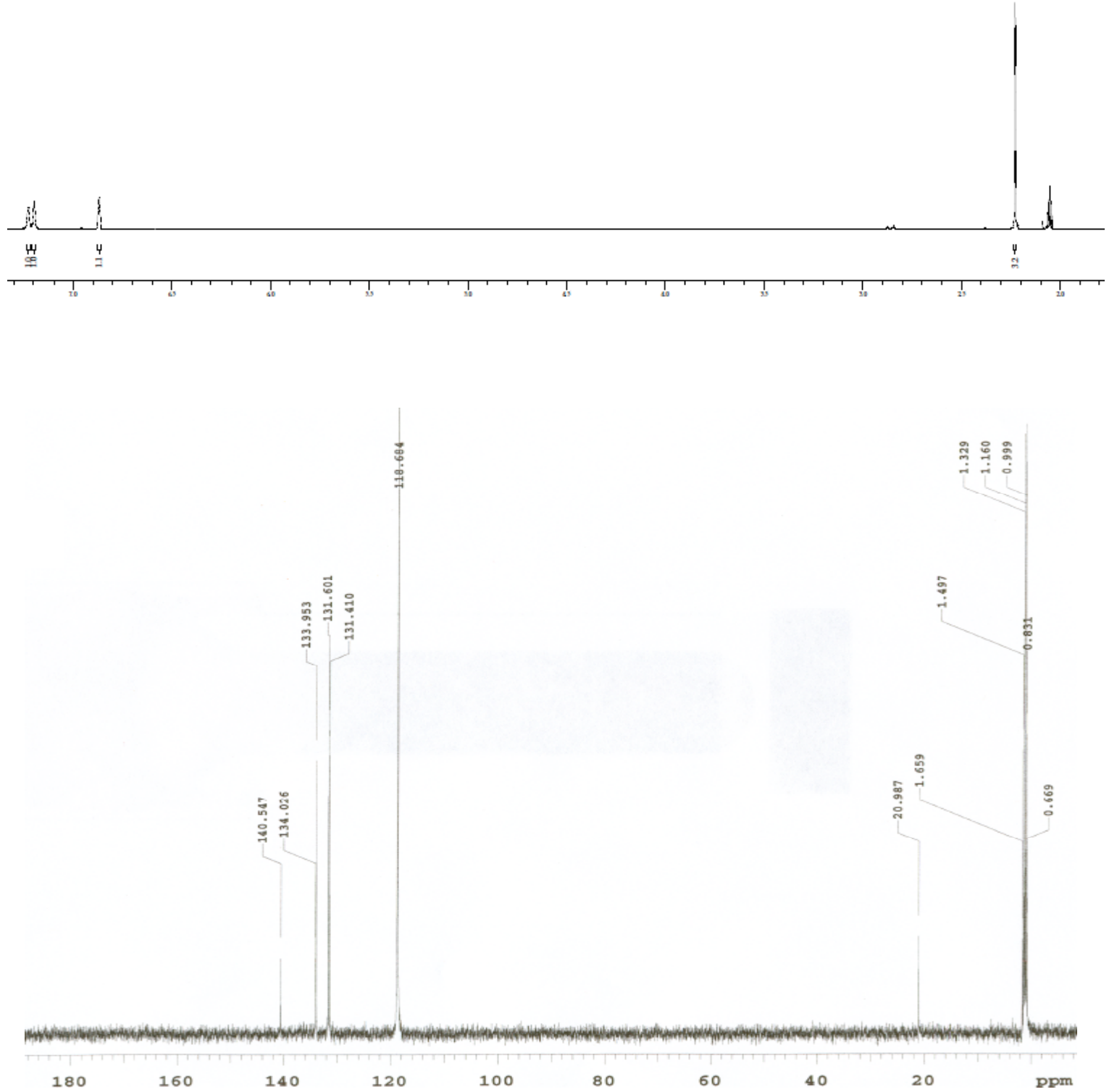


$$
\text { 1) }
$$

Table 3, Entry 10
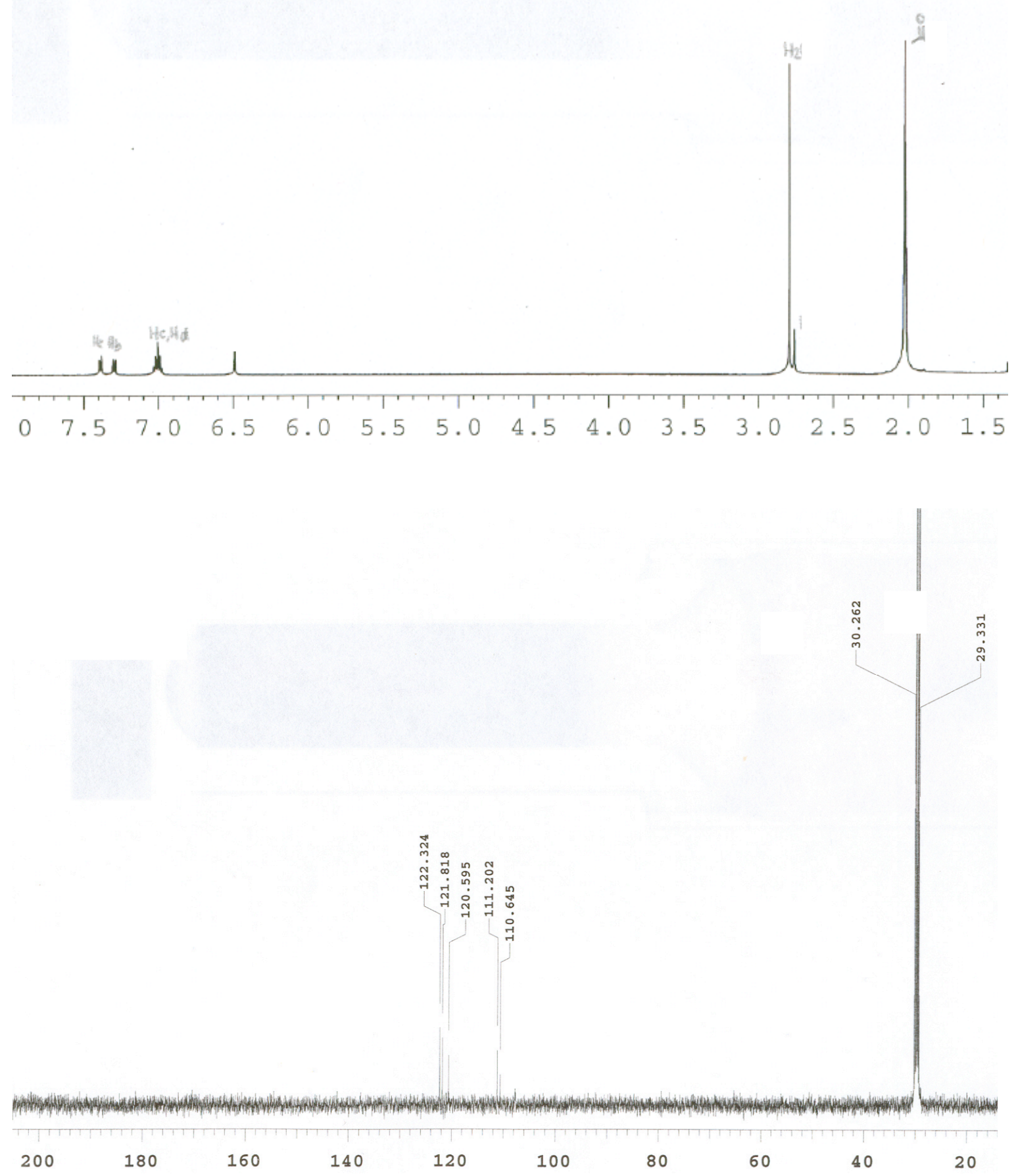
D- $\mathrm{BF}_{3} \mathrm{~K}$

Table 3, Entry 11

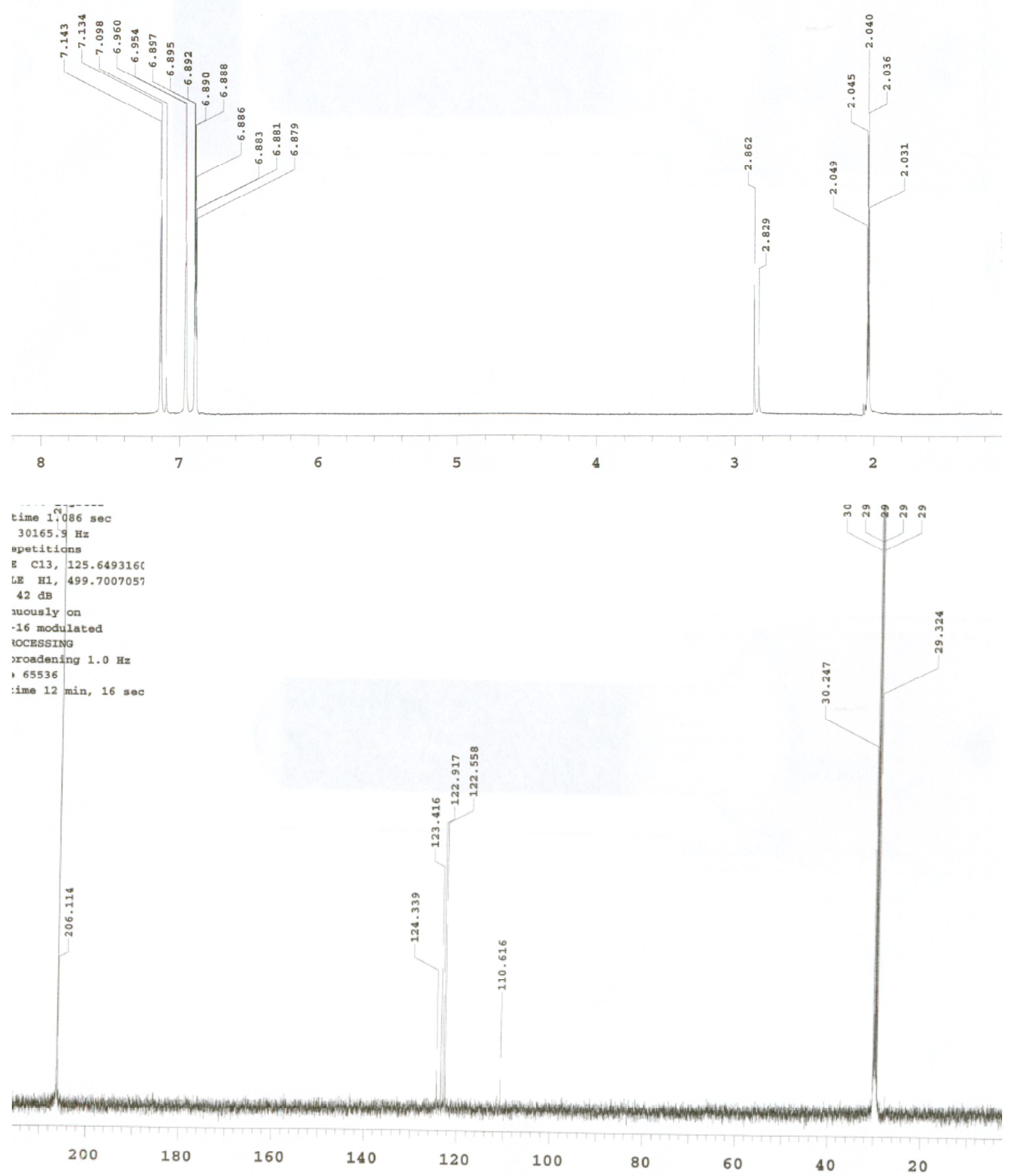

